

\section{DISCLAIMER}

This report was prepared as an account of work sponsored by an agency of the United States Government. Neither the United States Government nor any agency Thereof, nor any of their employees, makes any warranty, express or implied, or assumes any legal liability or responsibility for the accuracy, completeness, or usefulness of any information, apparatus, product, or process disclosed, or represents that its use would not infringe privately owned rights. Reference herein to any specific commercial product, process, or service by trade name, trademark, manufacturer, or otherwise does not necessarily constitute or imply its endorsement, recommendation, or favoring by the United States Government or any agency thereof. The views and opinions of authors expressed herein do not necessarily state or reflect those of the United States Government or any agency thereof. 


\section{DISCLAIMER}

Portions of this document may be illegible in electronic image products. Images are produced from the best available original document. 
Printed in the United States of America Available from

National Technical Information Service

U. S. Department of Commerce

5285 Port Royal Road

Springfield, VA 22161

NTIS price codes

Printed copy: A03

Microfiche copy: A01

\section{DISCLAIMER}

This report was prepared as an account of work sponsored by an agency of the United States Government. Neither the United States Government nor any agency thereof, nor any of their employees, makes any warranty, express or implied, or assumes any legal liability or responsibility for the accuracy, completeness, or usefulness of any information, apparatus, product, or process disclosed, or represents that its use would not infringe privately owned rights. Reference herein to any specific commercial product, process, or service by trade name, trademark, manufacturer, or otherwise, does not necessarily constitute or imply its endorsement, recommendation, or favoring by the United States Government or any agency thereof. The views and opinions of authors expressed herein do not necessarily state or reflect those of the United States Government or any agency thereof. 
Date of Issue: November 24, 1980

Y-2217

Distribution Category: UC-25

\title{
CORROSION EVALUATION OF COOLING-WATER TREATMENTS FOR GAS CENTRIFUGE FACILITIES
}

\author{
C. R. Schmitt \\ P. F. Meredith \\ Chemical Processes Department \\ Y-12 Development Division
}

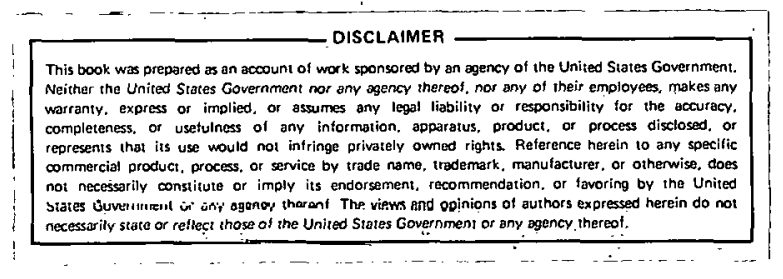

Oak Ridge $Y-12$ Plant

P. O. Box Y, Oak Ridge, Tennessee 37830

Prepares for the Department of Energy Under US Governmem Contract W-7405-eng-26 


\begin{abstract}
The corrosion resistance of six different types of weighed metal coupons was evaluated at $29^{\circ} \mathrm{C}\left(84^{\circ} \mathrm{F}\right)$ in flowing water containing nitrite-borate-silicate corrosion inhibitors.

The question for evaluation was whether it would be more advantageous (1) to drain the treated cooling water from the centrifuge machines and to expose them to moisture-laden air over an assumed shop downtime and repair period of 1 month or (2) to let the treated cooling water remain stagnant in the machines during this downtime. The moisture-laden-air exposure was more detrimental.
\end{abstract}




\section{CONTENTS}

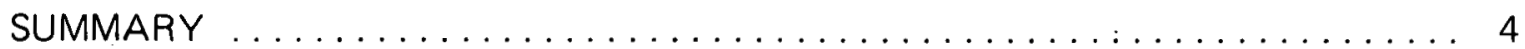

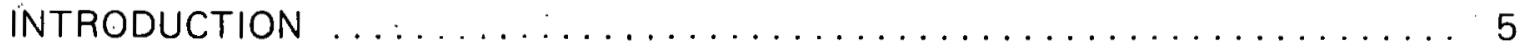

EVALUATION OF COOLANT TREATMENTS FOR GAS CENTRIFUGE FACILITIES ....................... 7

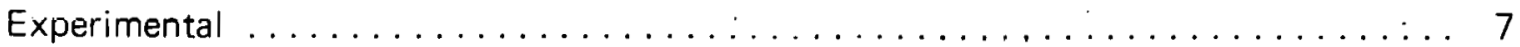

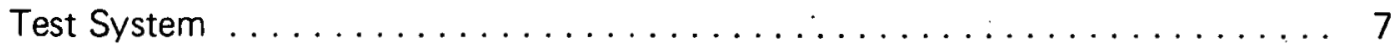

Description ............................... 7

Metal Coupon Holders $\ldots \ldots \ldots \ldots \ldots \ldots \ldots \ldots \ldots \ldots \ldots, 8$

Metal Coupons ............................ 9

Test-System Cleaning and Preparation . . . . . . . . . . . . . . 10

Corrosion Evaluation Tests .............................. 10

Dearborn-537 Corrosion Test . . . . . . . . . . . . . . . . . . . . 10

Y-12 Plant, DOE-Patented,

Corrosion-Inhibitory Formulation ................ 11

Dearborn-537, Stagnant-Water,

Air-Exposure Tests ......................... 19

Zimmite ZC-404 Corrosion Test . . . . . . . . . . . . . . . . . . . . . . . 26

Discussion ....................................... 33

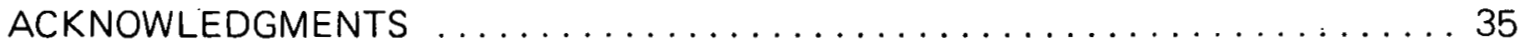

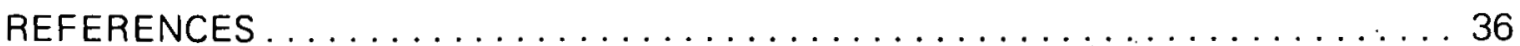




\section{SUMMARY}

Corrosion evaluation tests were conducted on six different types of metal coupons exposed to flowing water containing several nitrite-borate-silicate corrosion-inhibitor formulations of interest which have been proposed for the Oak Ridge Gaseous Diffusion Plant (ORGDP) Advanced Experimental Test Facility (AETF) and the Gas Centrifuge Enrichment Facility in Portsmouth, Ohio.

The six different types of metal coupons: steel, copper, Muntz metal, stainless steel, aluminum alloy 3003-H1, and aluminum alloy 6061-T6 were evaluated by weight-loss measurements and photomicrographs of the metal surfaces before and after water exposure. The corrosion tests were conducted at a temperature of $29^{\circ} \mathrm{C}\left(84^{\circ} \mathrm{F}\right)$, a water velocity of $182 \mathrm{~mm} / \mathrm{s}(0.6$ linear $\mathrm{fps})$, and an exposure time of $21 \mathrm{~d}$. 


\section{INTRODUCTION}

The general objective of this study, which was conducted at the Oak Ridge Y-12 Plant, (a) was to assess the degree of corrosion protection provided by various nitrite-borate-silicate water-treatment formulations on various metals associated with the ORGDP and the Portsmouth enrichment facilities.

The water-treatment formulations of interest were limited to the nitrite-borate-silicate compositions because these are relatively nontoxic and do not represent any serious health, handling, or waste-disposal problem as, for example, would hold true for chromatecontaining compositions.

A list of materials used in the centrifuge cooling-water system was provided ${ }^{1}$ and included steel, stainless steel, copper, brass, aluminum alloy 6061-T6, and aluminum alloy 3003- $\mathrm{H} 1$.

The test system to be used for evaluating the degree of corrosion protection provided by these cooling-water-treatment formulations was constructed in accordance with American Society for Testing and Materials (ASTM) standard test procedure. ${ }^{2}$

Corrosivity measurements in recirculating cooling waters (obtained by the use of metal specimens which are weighed before and after exposure to the water) do not give precise values of the corrosion to be expected on metal surfaces in the systems. Such measurements do. give a figure for the corrosion rate of the metal under the conditions tested, which is useful for comparative purposes. This is especially true when determining if the corrosion-inhibitive treatment being used in the system is giving adequate control. Examination of metal specimens can also give an indication of pitting tendencies and scale deposition.

The minimum-recommended duration of these tests is $30 \mathrm{~d}$. Tests can be extended with the use of multiple coupons for longer periods of time. It is also advisable that duplicate coupons be used, if time and space permit, to provide greater reliability of the corrosion-rate data. As a result of the urgent need for corrosion data at ORGDP, a 21-d water-exposure period has been used.

It was also stipulated by ORGDP that the proposed cooling-water test facility be run at a controlled water temperature of $29^{\circ} \mathrm{C}\left(84^{\circ} \mathrm{F}\right)$ and a water-flow rate of $5.7 \mathrm{~L} / \mathrm{min}(1.5 \mathrm{gpm})$ through $25-\mathrm{mm}$ (1-in.)-diameter piping. In addition to evaluating the corrosion of metal coupons by weight-loss data, it was also agreed that photomicrography of the metal coupon surface before and after water exposure would be useful for detecting any incipient pitting. Microbiological control for aerobic bacteria, anaerobic bacteria, and fungi were monitored

(a) Operated by the Union Carbide Corporation, Nuclear Division, for the Department of . Energy. 
by using Orion Easicult Diagnostica (b) agar slide tests. To ensure proper control of inhibitor concentrations for each cooling-water-treatment evaluation, the necessary laboratory analytical data for $\mathrm{pH}$ and for dissolved-ionic constituents were also obtained.

(b) Distributed in the United States by Metal Work Chemicals and Equipment Co., Chester, N. Y. 


\section{EVALUATION OF COOLANT TREATMENTS FOR GAS CENTRIFUGE FACILITIES}

\section{EXPERIMENTAL}

\section{Test System}

Description - A diagrammatic representation of the water-corrosion test system used for evaluating the inhibitory corrosion formulations is shown in Figure 1. Essentially, the

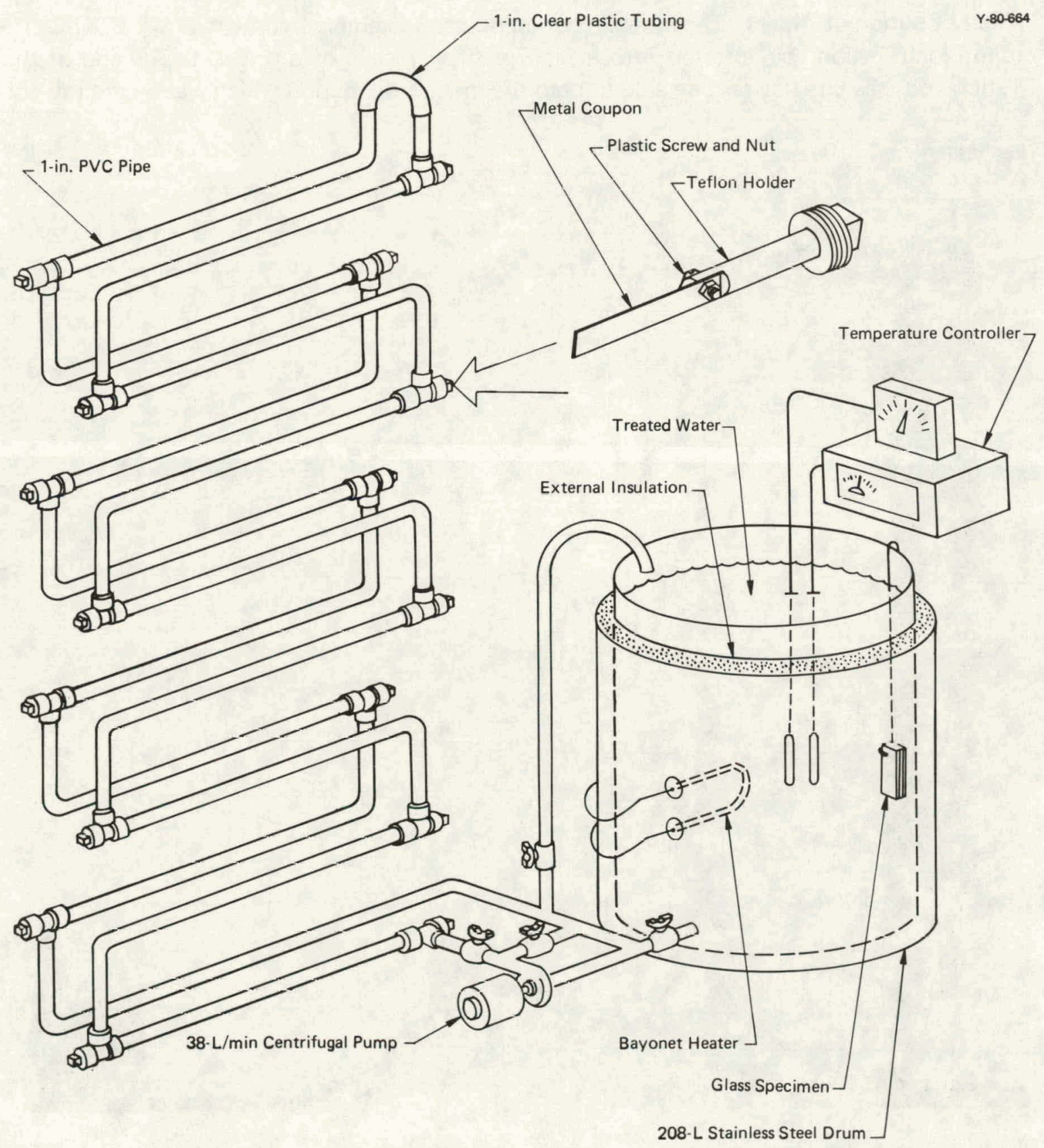

Figure 1. DIAGRAMMATIC REPRESENTATION OF WATER-CORROSION TEST SYSTEM. 
system consisted of an insulated, stainless steel, 208-L (55-gal) drum containing an electrical bayonet heater and an automatic temperature controller, a 0.63- $\mathrm{L} / \mathrm{s}(10-\mathrm{gpm})$ centrifugal pump, and a vertical array of 25 -mm (1-in.)-diameter polyvinyl chloride $\left[\left(-\mathrm{H}_{2} \mathrm{CCHCl}-\right)_{X}\right]$ (PVC) piping. A bypass line and valve led from the vertical piping array to the drum which allowed the flow of water through the piping array to be controlled to $5.7 \mathrm{~L} / \mathrm{min}(1.5 \mathrm{gpm})$ which is equivalent to the desired water-velocity condition specified through the piping and the corrosion-coupon holders of $182 \mathrm{~mm} / \mathrm{s}(0.6$ linear $\mathrm{fps})$. A photograph of the actual water-corrosion-test-system installation is shown in Figure 2.

Metal Coupon Holders - The metal-coupon-holder assembly consisted of a 152-mm (6-in.)-long Teflon rod inserted into a pipe plug by means of a drive fit. The end of the Teflon rod was cut flat on one side to hold the metal test coupon which was secured to the

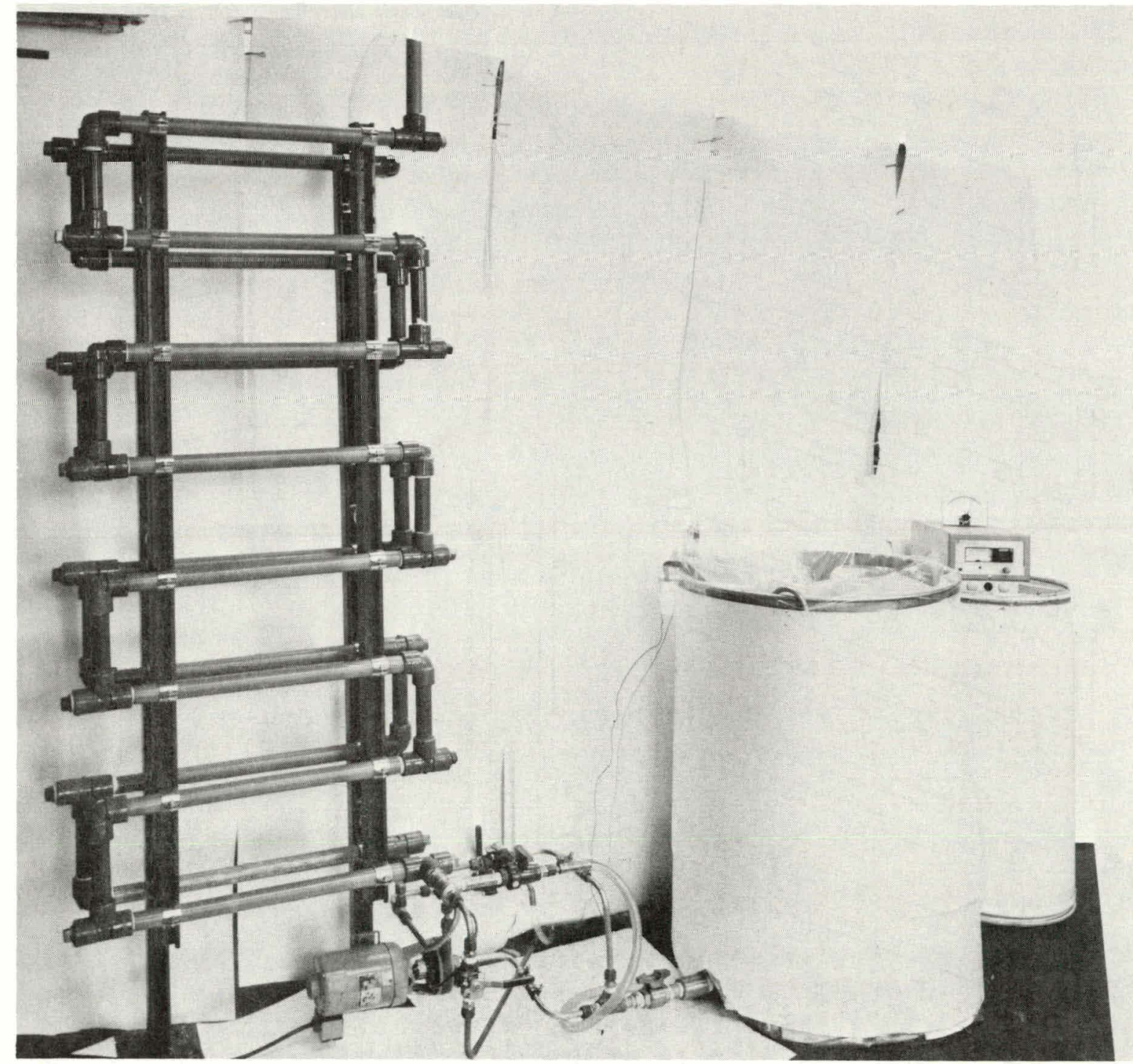

Figure 2. WATER-CORROSION TEST SYSTEM. 
Tefion rod by a plastic screw and a plastic nut to prevent any bimetallic junctions. The specimen-holder assembly was connected so that the water would flow upward through it, and the pipe would be completely full of water at all times. A diagram showing details of the metal-coupon-holder assembly and the placement of the coupons with respect to water flow is shown in Figures 3 and 4 , respectively.

Metal Coupons - The metal test coupons were prepared from low-carbon, coldrolled steel, stainless steel (Type 304L), copper, Muntz metal, aluminum alloy 3003-H1, and aluminum alloy 6061-T6all as specified by ORGDP to match the metal components of the centrifuge cooling-water system. The coupon dimensions were 0.5 -in. wide by 4 -in. long. by $1 / 8$-in. thick $(12.7 \mathrm{~mm} \times 101.6 \mathrm{~mm} X$ $3.2 \mathrm{~mm}$ ) and: were prepared from sheet metal by shearing from a strip of the proper width. The hole to fasten the specimen in place on the Tetlon holder was drilled, rather than punched, near one:end of the coupon. Sheared edges were eliminated by rounding off with abrasive emery paper. Numbers for identification of the test coupon were stamped in the metal between the hole and the end. Fiducial markings $(A)$ and (B) were made on both sides of the ends of the coupons to permit photomicrographic studies of the same area of metal surface to be made before and after water exposure.

The metal coupons were grit blasted with clean, dry, aluminum oxide $\left(\mathrm{Al}_{2} \mathrm{O}_{3}\right)$, abrasive particles (approximately 50 to 60 mesh) and degreased with perchloroethylene $\left(\mathrm{Cl}_{2} \mathrm{C}: \mathrm{CCl}_{2}\right)$. The specimens were subsequently handled with cotton gloves and stored in separate, clean, kraft envelopes (after being weighed) and sealed into an outer, plastic, edge-lock

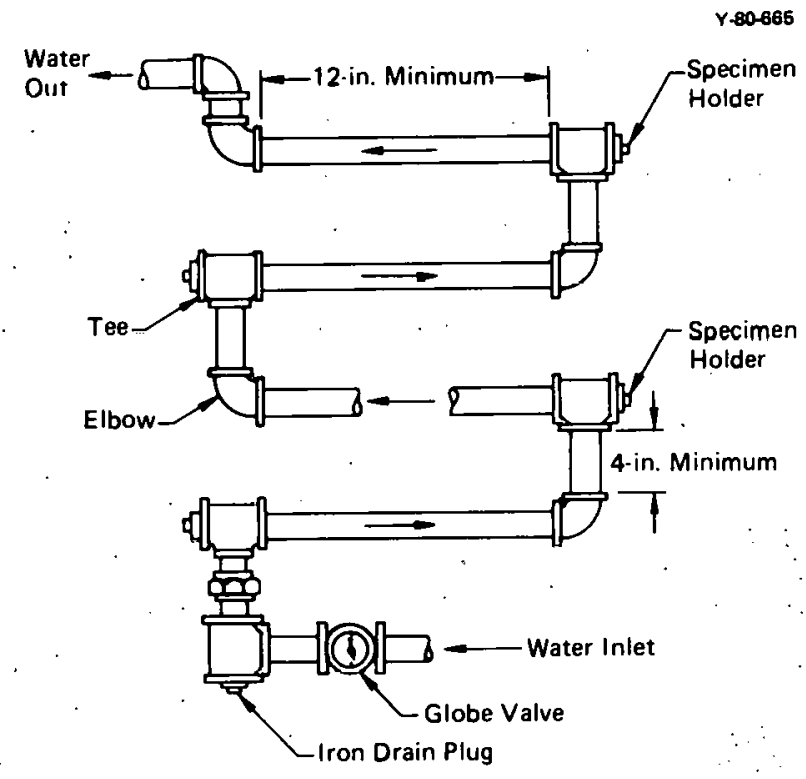

Figure 3. CORROSION-TEST SPECIMEN-HOLDER ASSEMBLY.

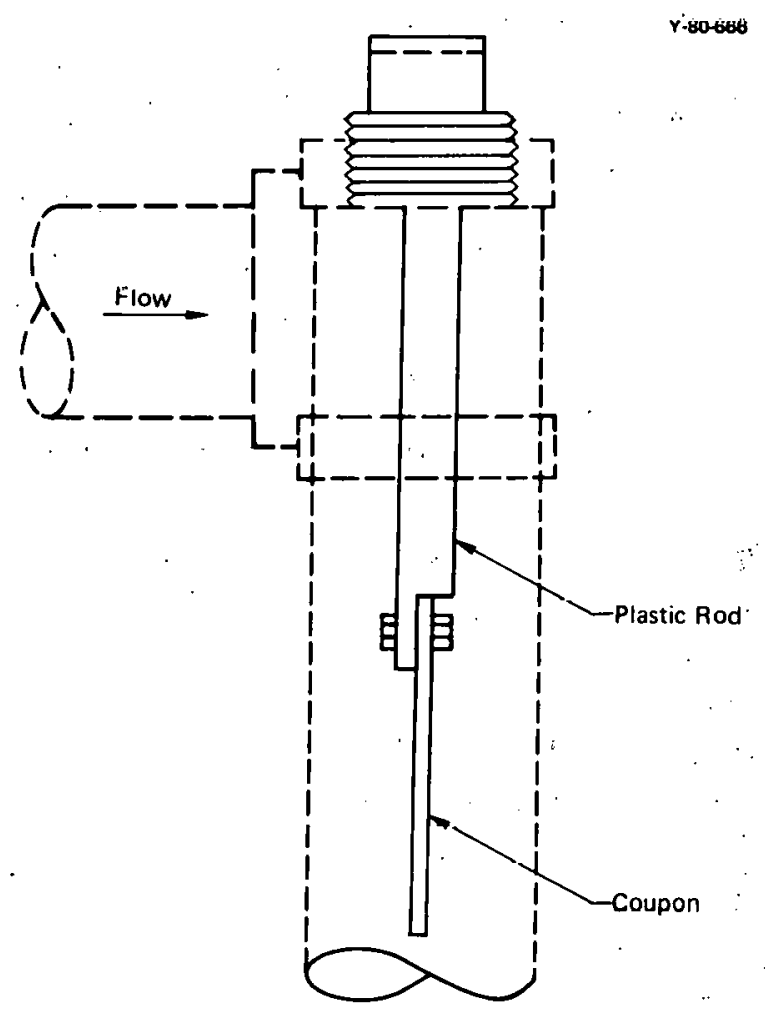

Figure 4. DETAIL DIAGRAM SHOWING PLACEMENT OF CORROSION-TEST SPECIMEN. 
envelope containing a small packet of dehydrated-silica-gel desiccant. The metal coupons were weighed to the nearest $0.1 \mathrm{mg}$ prior to insertion into the cooling-water test system.

Test-System Cleaning and Preparation-The assembled pilot-plant water system was degreased and cleaned by first circulating an aqueous solution of detergent through it. Demineralized water was circulated through the system to assure that the system was free of PVC threads and shavings, detergent, or other dirt and debris that may have entered from pipe-fitting operations. The suitability of a stainless steel, electrical heater and electrical controls to maintain water temperatures at $29 \pm 1^{\circ} \mathrm{C}\left(84 \pm 2^{\circ} \mathrm{F}\right)$ was checked. The water flow through the bypass line was calibrated by adjusting the valve settings to maintain the desired $1.5 \mathrm{gpm}(95 \mathrm{~mL} / \mathrm{s})$.

Sanitary drinking water was obtained from ORGDP, and the system was filled with $30 \mathrm{gal}$ $(114 \mathrm{~L})$ of sanitary water. The water-treating chemicals were added to the system in prescribed, calculated amounts. A sample of the treated water was obtained for laboratory analytical reference data, and the weighed metal test coupons were installed after a record of surface irregularities on the metal test coupons had been obtained by photomicrography. After 21-d exposure in the water system, the system was drained; and metal specimens were maintained in their holders while exposed to an ambient moist atmosphere at room temperature $\left(25^{\circ} \mathrm{C}\right)$ for $4 \mathrm{~d}$. The metal test coupons were then removed and evaluated for corrosion by weight loss and/or photomicrography of exposed surfaces.

\section{Corrosion Evaluation Tests}

Dearborn-537(c) Corrosion Test - Corrosion tests on the first water-treatment formulation of interest were made with Dearborn-537, and the test water system was operated continuously for $21 \mathrm{~d}$ at $29^{\circ} \mathrm{C}\left(84^{\circ} \mathrm{F}\right)$ : The water-flow rate through the 1.0 -in. $(15-\mathrm{mm})$-diameter PVC piping was controlled at $1.5 \mathrm{gpm}(5.7 \mathrm{~L} / \mathrm{min})$ which is equivalent to a water velocity of 0.6 linear fps $(182 \mathrm{~mm} / \mathrm{s})$. The system was drained of water, and the various corrosion test coupons were allowed to remain exposed to the moisture-laden-air environment within the PVC piping system for $4 \mathrm{~d}$ at room temperature before they were removed for corrosion and film build-up evaluation purposes.

Six, different, metal types were evaluated by weight-loss measurements and photomicrography before and after water exposure. Weight-change data are summarized in Table 1.

As shown in Table 1, the weight changes observed for most of the metal types tested were negligible, except for steel which showed an average weight loss of $0.9 \mathrm{mg}$ for the two metal coupons used. Corrosion-rate calculations using this average weight loss for steel show a

(c) Chemed Corporation, Dearborn Chemical Division, Lake Zurich, III. 
Table 1

CORROSION-TEST-COUPON WEIGHT CHANGES ACCOMPANYING DEARBORN-537 WATER TREATMENT

\begin{tabular}{clrrr}
\hline & \multicolumn{1}{c}{ Metal Type } & \multicolumn{3}{c}{ Weight (g) } \\
\cline { 3 - 5 } Specimen & \multicolumn{1}{c}{ Initial } & \multicolumn{1}{c}{ Final } & Change \\
\hline M-1 & Aluminum Alloy 3003-H1 & 5.0300 & 5.0304 & +0.0004 \\
A-1 & Aluminum Alloy 6061-T6 & 6.1318 & 6.1320 & +0.0002 \\
$20-N$ & Steel & 13.7136 & 13.7128 & -0.0008 \\
$23-N$ & Steel & 13.6971 & 13.6961 & -0.0010 \\
AA-1 & Copper & 21.4054 & 21.4055 & +0.0001 \\
AA-2 & Copper & 21.3044 & 21.3044 & 0.0000 \\
BM-1 & Muntz Metal (60\% copper, 40\% zinc) & 19.5294 & 19.5297 & +0.0003 \\
SS-1 & Stainless Steel 304L & 17.1367 & 17.1364 & -0.0003 \\
\hline
\end{tabular}

corrosion rate of $0.15 \mathrm{mg} / \mathrm{dm}^{2} / \mathrm{d}\left(170 \mathrm{mg} / \mathrm{m}^{2} / \mathrm{s}\right)$ which is equivalent to $0.028 \mathrm{mil}$ per year in average corrosion-penetration-rate units. These calculations were made on the basis of an exposed metal surface area of $0.290 \mathrm{dm}^{2}$, an exposure period of $21 \mathrm{~d}$, and a density of $7.87 \mathrm{~g} / \mathrm{mL}$ for steel.

The Dearborn-537 test was made using a 114-L (30-gal) volume of ORGDP sanitary water and Dearborn-537 concentrate. The Dearborn-537 concentrate was diluted with the ORGDP sanitary water in the volume ratio of 1:100 as per instructions. Samples of the ORGDP sanitary water and the Dearborn-537-treated sanitary water at the start and end of the 21-d corrosion test were taken for laboratory analyses. Laboratory analyses are summarized in Table 2.

Orion Diagnostica Easicult slide tests for microbiological contamination taken at the start of the Dearborn-537 test were negative; but after $21 \mathrm{~d}$, the presence of approximately $105 / \mathrm{mL}$ aerobic bacteria organisms was indicated by the Easicult TTC culture medium.

Visual examination of flat glass surfaces and nylon surfaces that were immersed in the Dearborn-537-treated water for the 21-d test did not show any visible scale or film residues.

Photomicrographs of the metal coupon surfaces before and after exposure to Dearborn-537-treated water for $21 \mathrm{~d}$ at $29^{\circ} \mathrm{C}\left(84^{\circ} \mathrm{F}\right)$ are presented in Figures 5 through 10 .

Y-12 Plant, DOE-Patented, (d) Corrosion-Inhibitory Formulation - Corrosion-rate data on the second water-treatment formulation of interest, a DOE-patented blend of nitrite-borate-silicate corrosion inhibitors, boric acid $\left(\mathrm{H}_{3} \mathrm{BO}_{3}\right)$ for $\mathrm{pH}$ control, and 30-ppm poly [oxyethylene(dimethyl-iminio)ethylene(dimethyl-iminio)ethylenedichloride] as a microbiocide were obtained after the immersion of six different types of metal coupons (in

(d) Patent applied tor by J. R. LeMonbrun and C. K. Schmitt. 
Table 2

SUMMARY OF WATER ANALYSES ACCOMPANYING DEARBORN-537 TEST

\begin{tabular}{|c|c|}
\hline \multicolumn{2}{|c|}{ ORGDP Sanitary Water (Requisition 379699) } \\
\hline $\mathrm{pH}$ & 7.5 \\
\hline Hardness (ppm as $\mathrm{CaCO}_{3}$ ) & 122 \\
\hline M-Alkalinity (ppm as $\mathrm{CaCO}_{3}$ ) & 91 \\
\hline Total Dissolved Solids (ppm) & 169 \\
\hline \multicolumn{2}{|c|}{ Dearborn-537-Treated Water at Start of Test (Requisition 379700) } \\
\hline $\mathrm{pH}$ & 9.3 \\
\hline Total Organic Carbon (mg/L) & 34 \\
\hline Boron (ppm as $B$ ) & 262 \\
\hline Nitrite (ppm as $\mathrm{NO}_{2}$ ) & 814 \\
\hline Silicate (ppm as $\mathrm{SiO}_{2}$ ) & 118 \\
\hline \multicolumn{2}{|c|}{ Dearborn-537-Treated Water at End of Test (Requisition 379708) } \\
\hline $\mathrm{pH}$ & 9.4 \\
\hline Total Organic Carbon (mg/L) & 32 \\
\hline Boron (ppm as $\mathrm{B}$ ) & 127 \\
\hline Nitrite (ppm as $\mathrm{NO}_{2}$ ) & 898 \\
\hline Silicate $\left(\mathrm{ppm}\right.$ as $\left.\mathrm{SiO}_{2}\right)$ & 113 \\
\hline Specific Conductance $(\mu \mathrm{mho} / \mathrm{cm})$ & 3077 \\
\hline Total Dissolved Solids (ppm) & 2790 \\
\hline
\end{tabular}

duplicate) for $21 \mathrm{~d}$ at $29^{\circ} \mathrm{C}\left(84^{\circ} \mathrm{F}\right)$ followed by exposure to a moisture-laden-air environment inside the $25-\mathrm{mm}$ ( 1 -in.)-diameter PVC piping system at ambient temperature for $4 \mathrm{~d}$.

Weight-change data obtained on the metal coupons are summarized in Table 3.

Table 3

CORROSION WEIGHT CHANGES USING Y-12, DOE-PATENTED WATER-TREATMENT FORMULATION

\begin{tabular}{clrrr}
\hline & & \multicolumn{3}{c}{ Weight $(\mathrm{g})$} \\
\cline { 3 - 5 } Specimen & \multicolumn{1}{c}{ Metal Type } & Initial & Final & Change \\
\hline SS-3 & Stainless Steel 304L & 17.2538 & 17.2536 & -0.0002 \\
BM-3 & Muntz Metal (60\% copper, 40\% zinc) & 19.6594 & 19.6593 & -0.0001 \\
$79 N$ & Steel & 13.7000 & 13.6999 & -0.0001 \\
M-3 & Aluminum Alloy 3003-H1 & 5.0173 & 5.0179 & +0.0006 \\
A-3 & Aluminum Alloy 6061-T6 & 6.1687 & 6.1688 & +0.0001 \\
AA-4 & Copper & 21.1879 & 21.1876 & -0.0003 \\
$61-N$ & Steel & 13.7080 & 13.7079 & -0.0001 \\
AA-3 & Copper & 21.5907 & 21.5900 & -0.0007 \\
SS-2 & Stainless Steel 304L & 17.2070 & 17.2070 & - \\
BM-2 & Muntz Metal (60\% copper, 40\% zinc) & 19.6048 & 19.6042 & -0.0006 \\
M-2 & Aluminum Alloy 3003-H1 & 4.9607 & 4.9617 & +0.0010 \\
A-2 & Aluminum Alloy 6061-T6 & 6.2189 & 6.2188 & -0.0001 \\
\hline
\end{tabular}




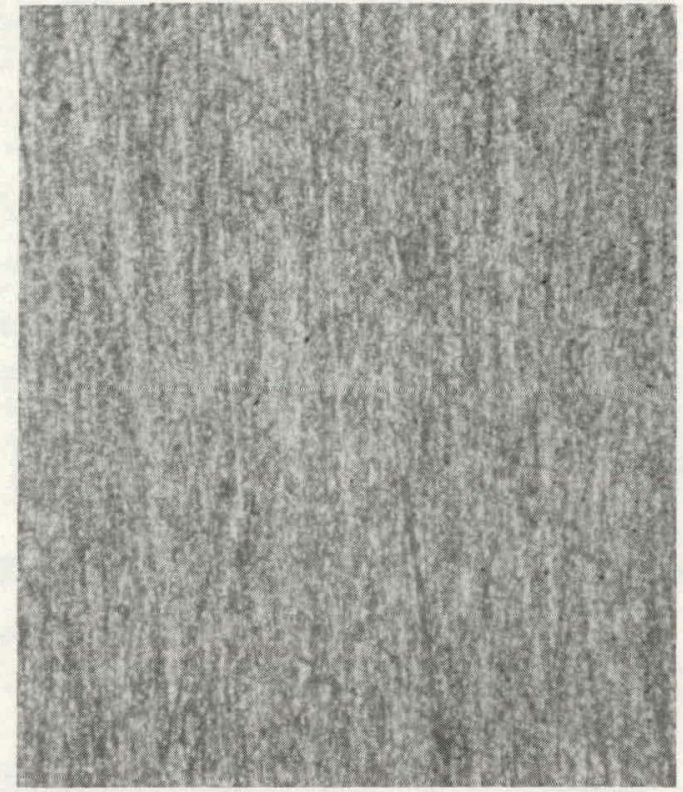

(a) Side A, before.

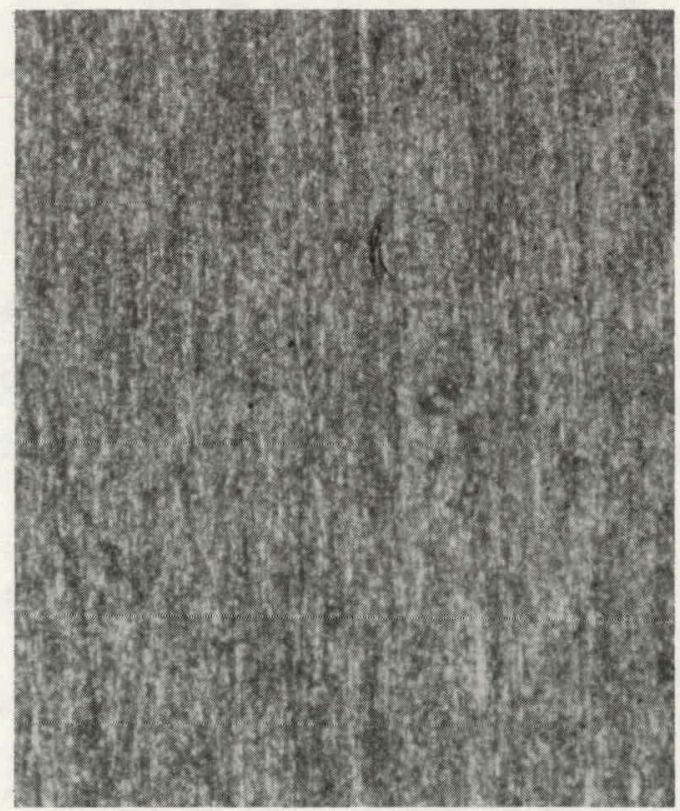

(c) Side B, before.

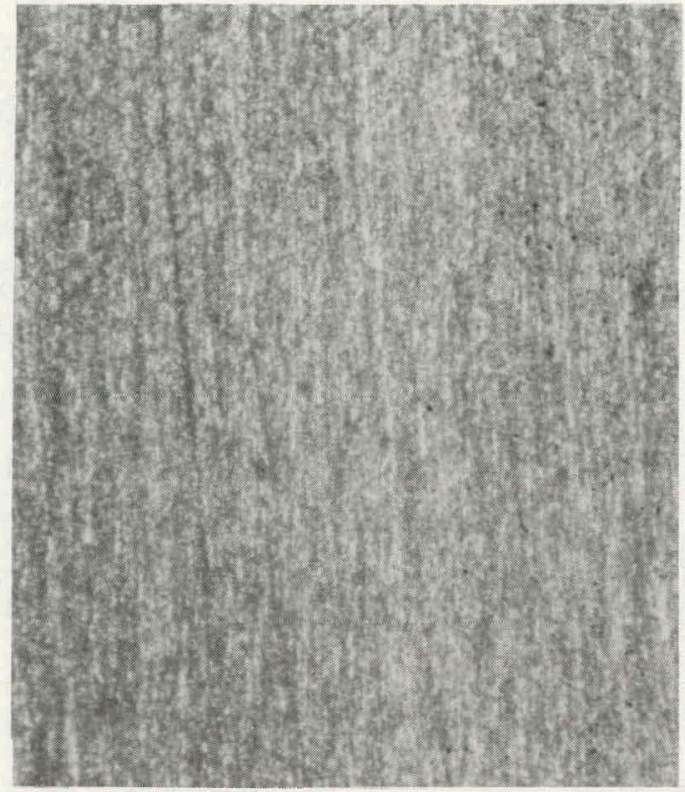

(b) Side A, after.

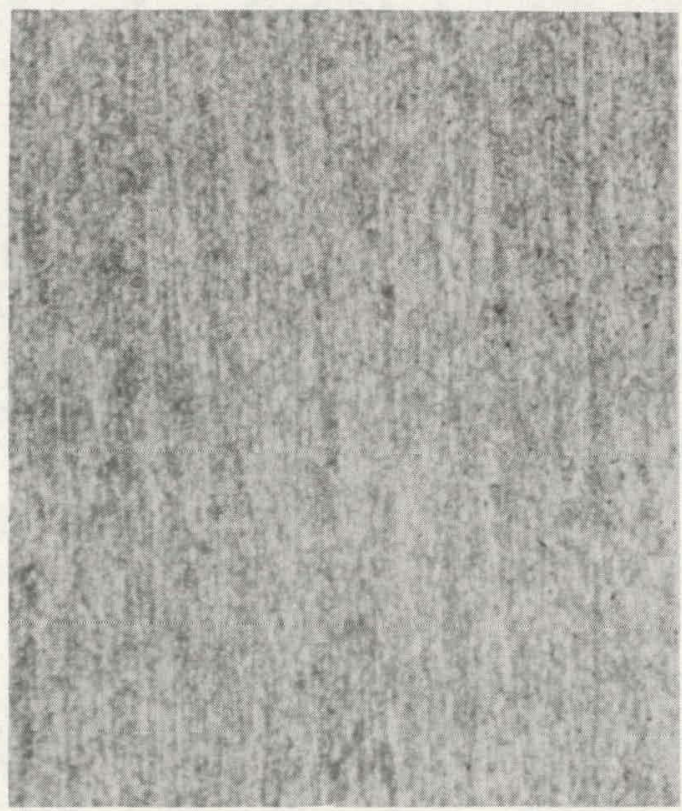

(d) Side B, after.

Figure 5. ALUMINUM ALLOY 3003-H1; DEARBORN-537 TREATMENT (21 DAYS AT $84^{\circ} \mathrm{F}$ ). (50X) 


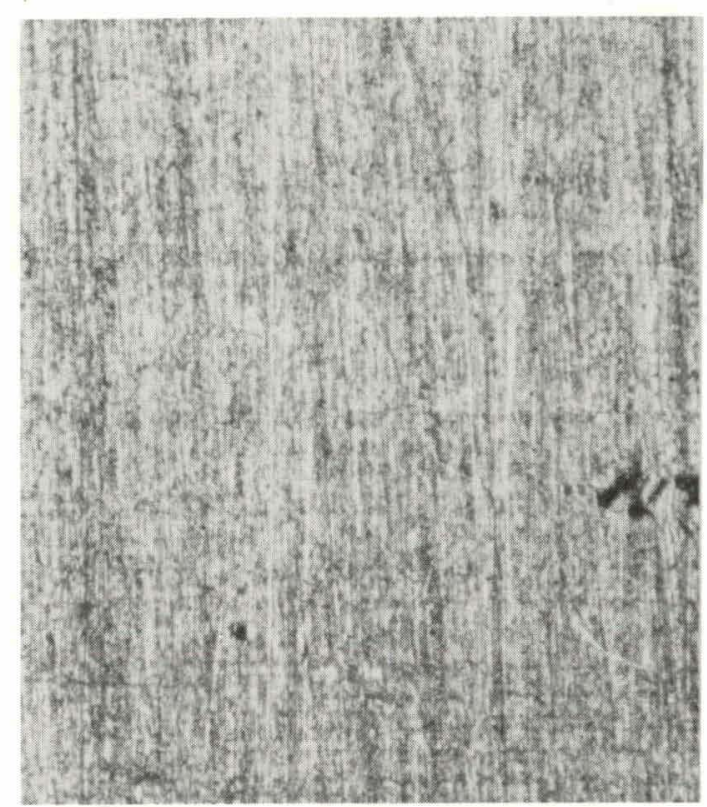

(a) Side A, before.

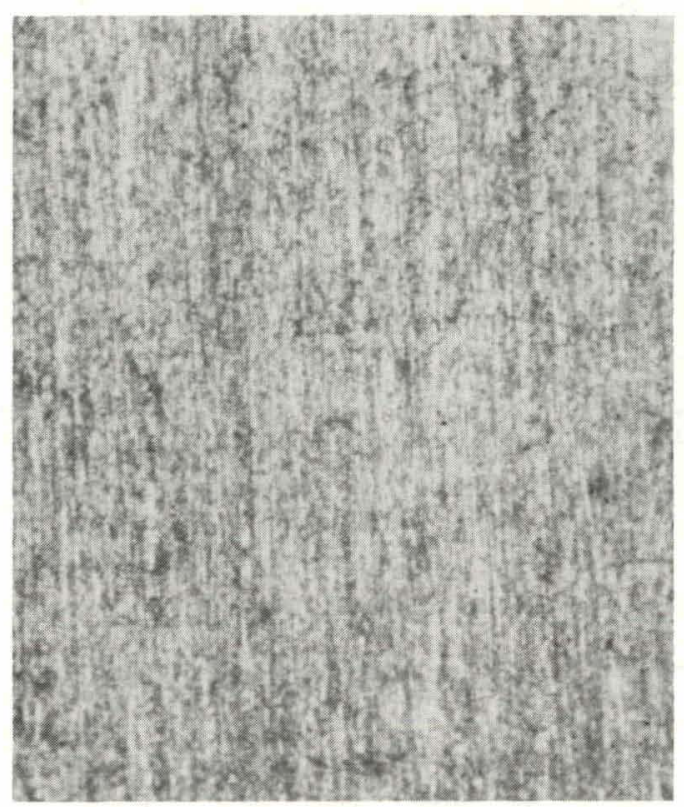

(b) Side $A$, after.

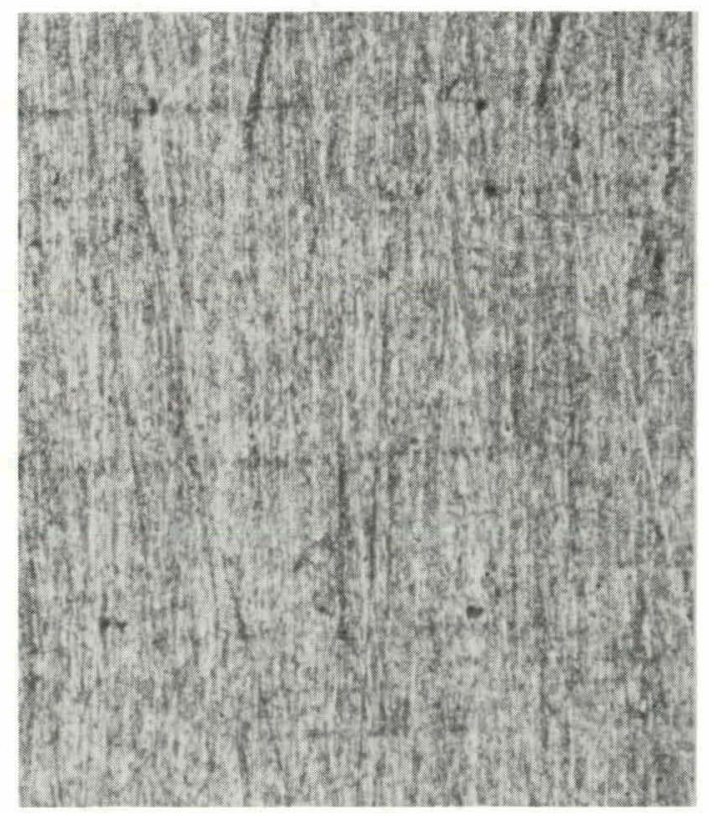

(c) Side B, before.

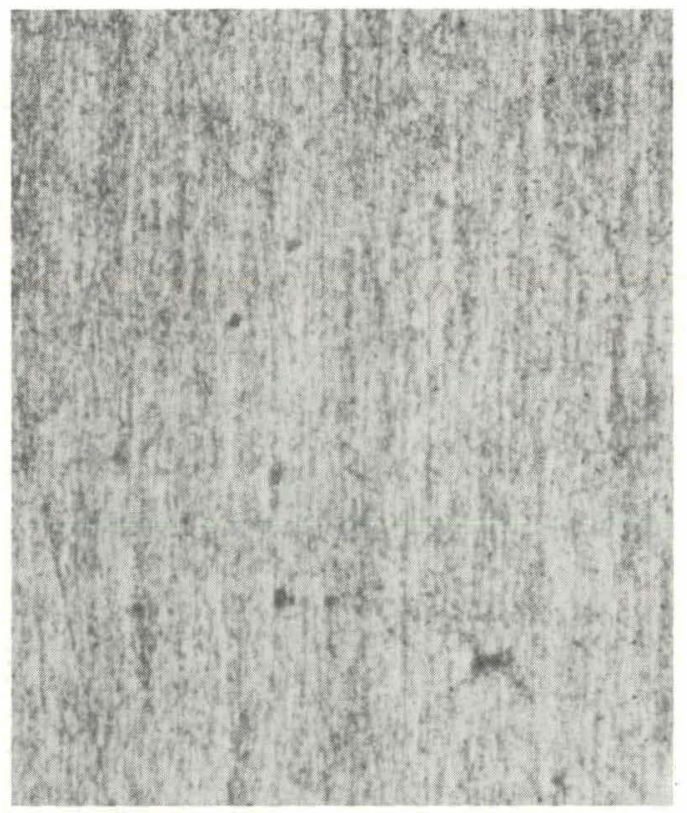

(d) Side B, after.

Figure 6. ALUMINUM ALLOY 6061-T6; DEARBORN-537 TREATMENT (21 DAYS AT $84^{\circ} \mathrm{F}$ ). (50X) 


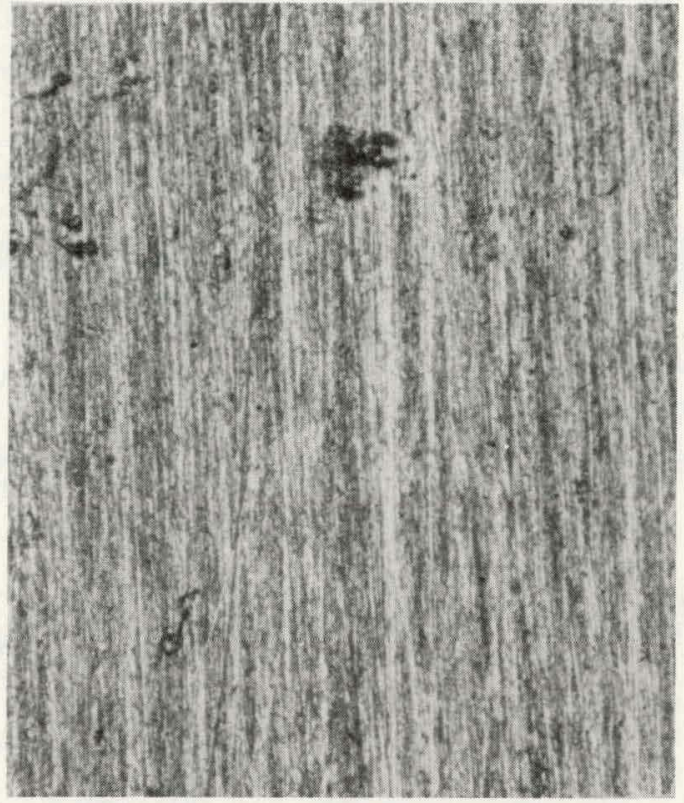

(a) Side A, before.

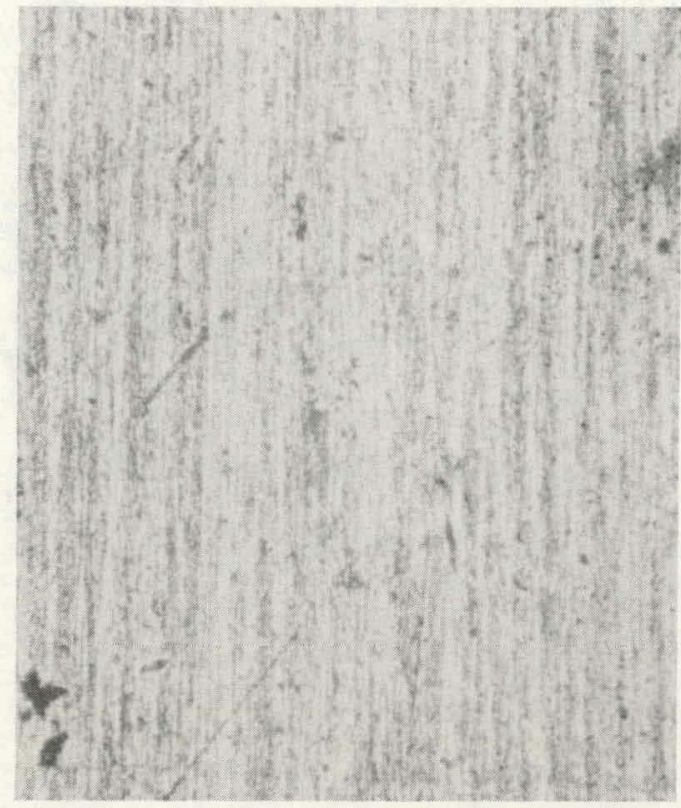

(b) Side A, after.

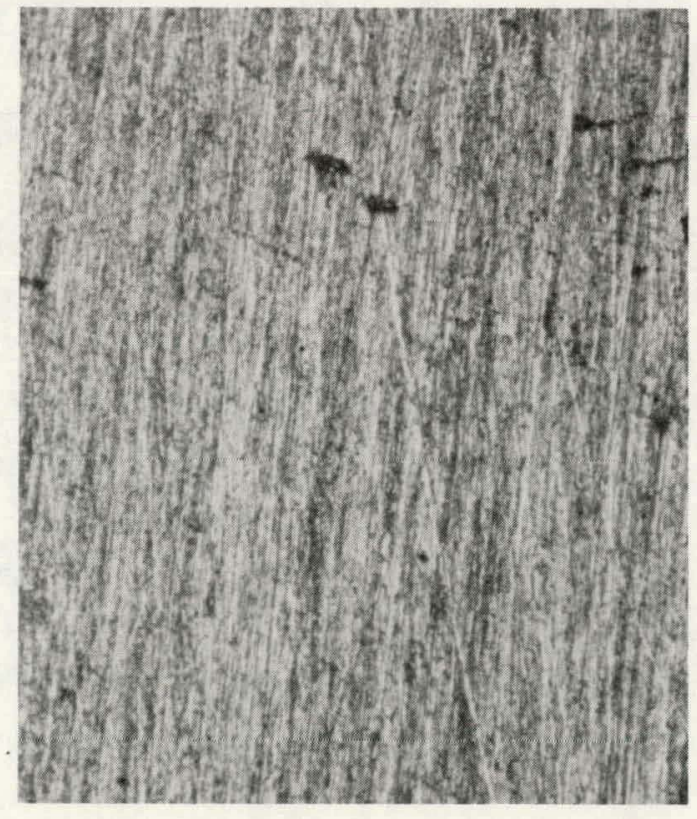

(c) Side B, before.

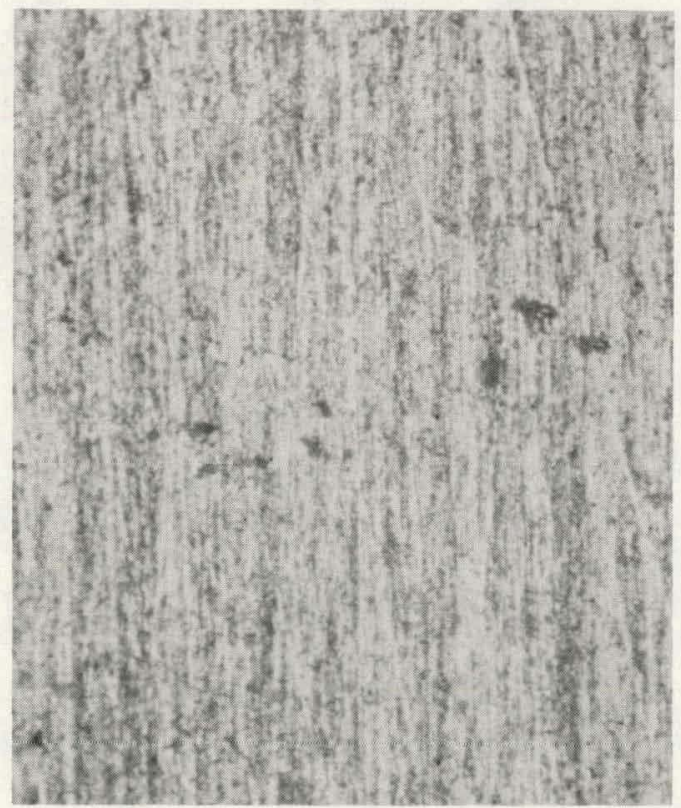

(d) Side B, after.

Figure 7. COPPER; DEARBORN-537 TREATMENT (21 DAYS AT $84^{\circ}$ F). (50X) 


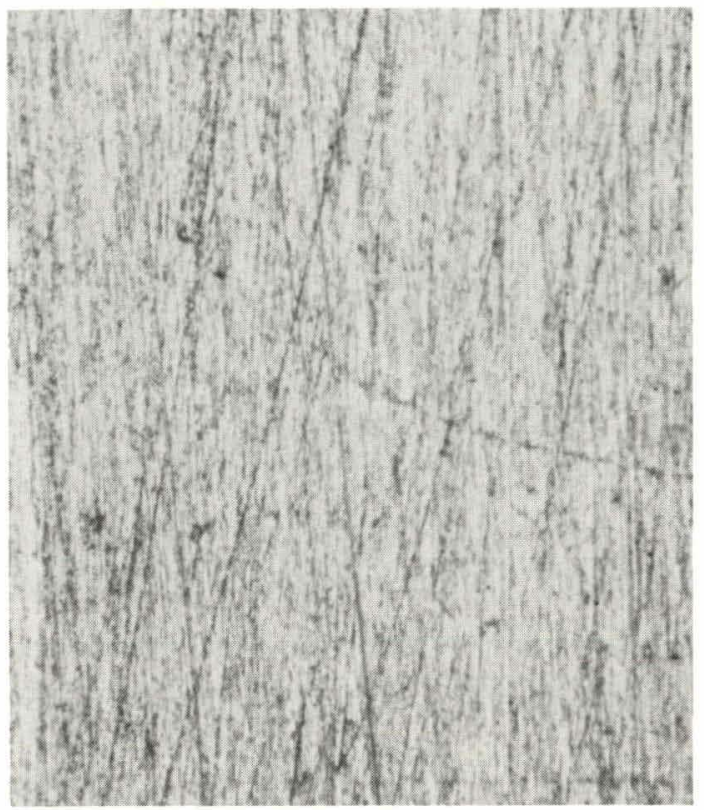

(a) Side A, before.

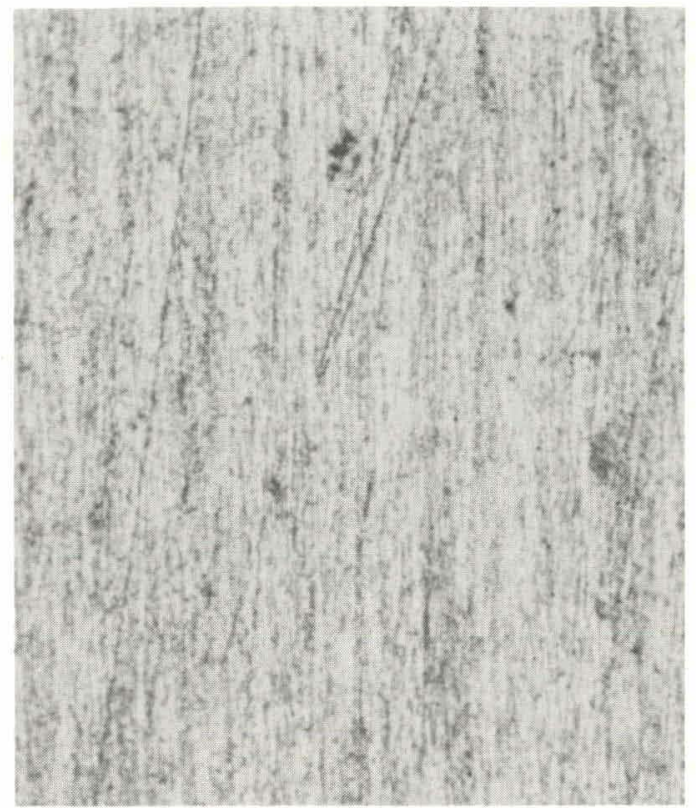

(b) Side $\mathbf{A}$, after.

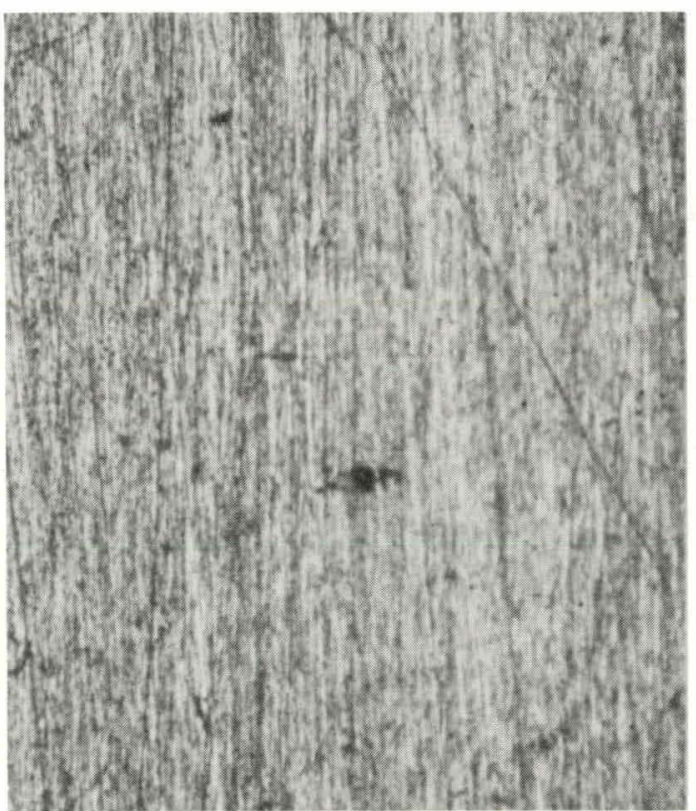

(c) Side B, before.

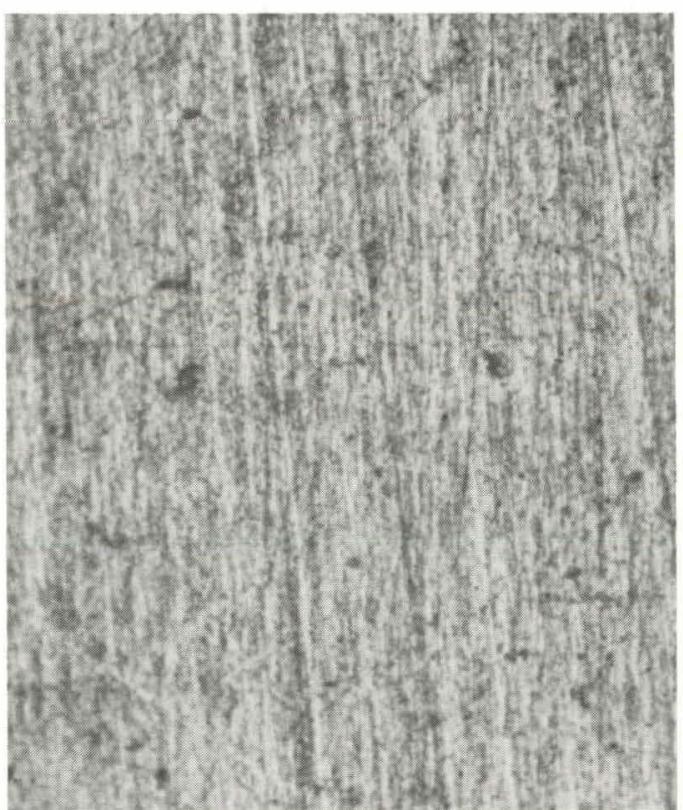

(d) Side B, after.

Figure 8. MUNTZ METAL; DEARBORN-537 TREATMENT (21 DAYS AT $84^{\circ} \mathrm{F}$ ). (50X) 


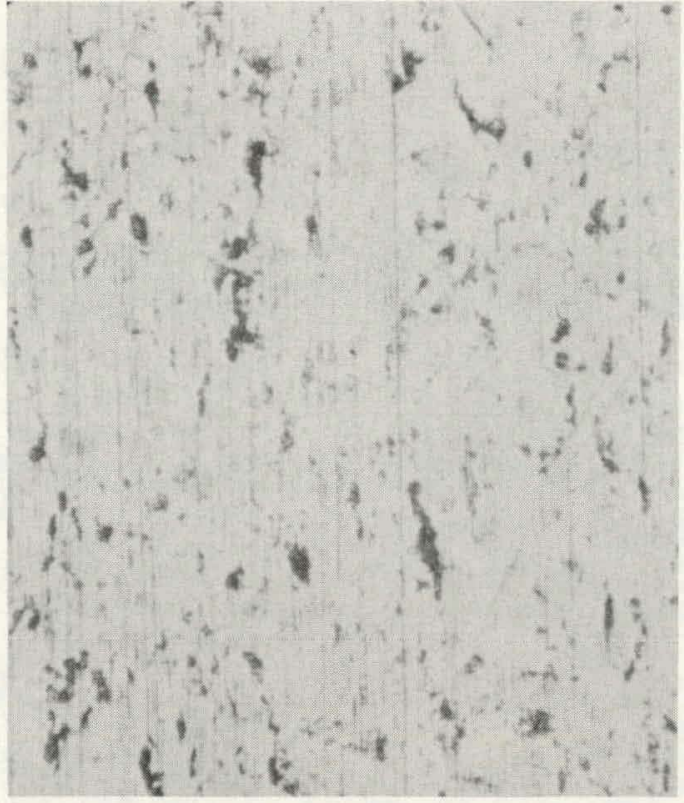

(a) Side A, before.

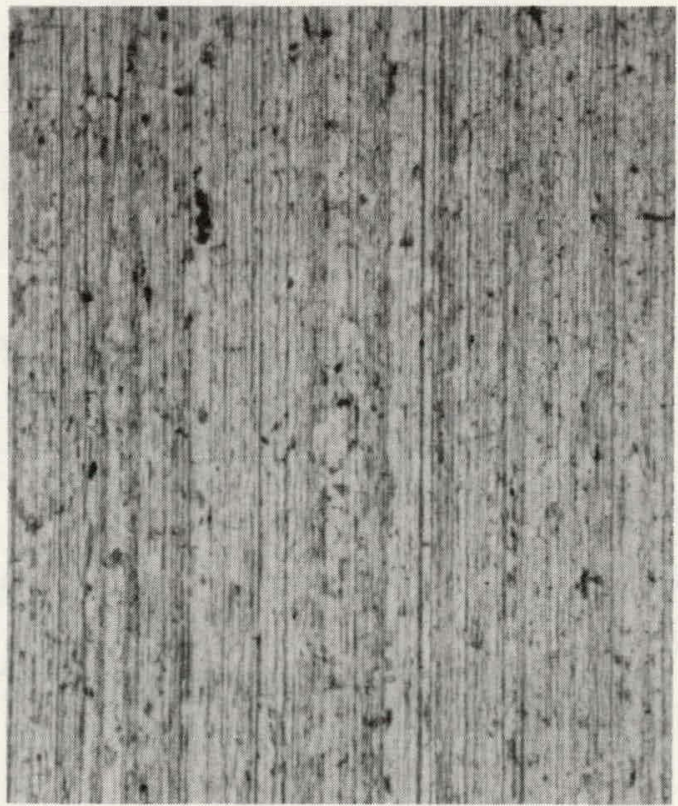

(c) Side B, before.

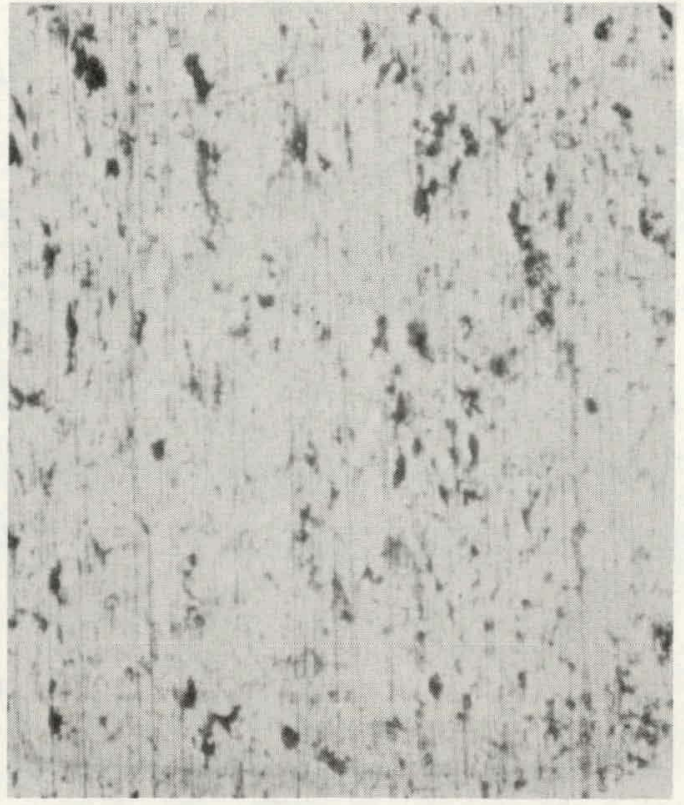

(b) Side A, after.

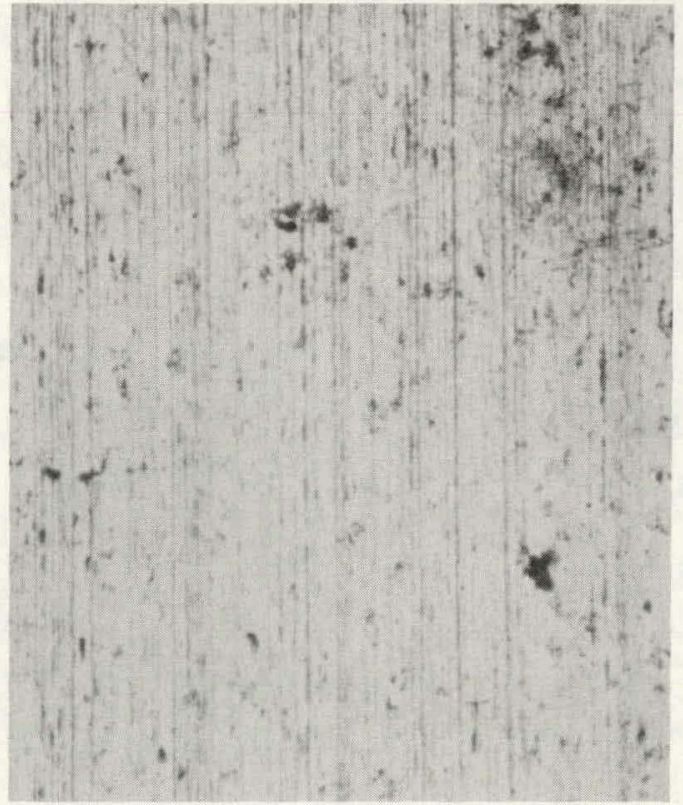

(d) Side B, after.

Figure 9. STEEL; DEARBORN-537 TREATMENT (21 DAYS AT $84^{\circ} \mathrm{F}$ ). (50X) 


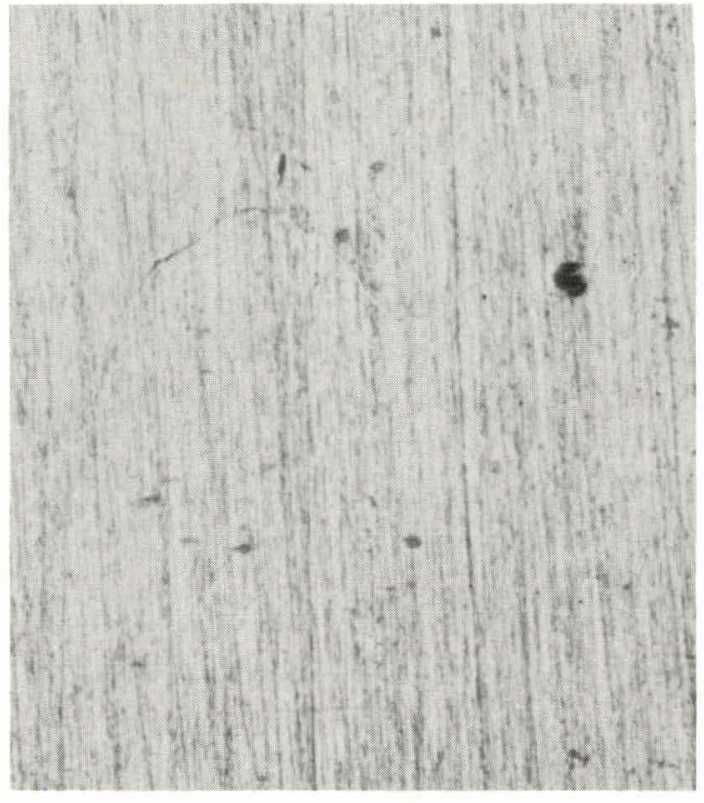

(a) Side A, before.

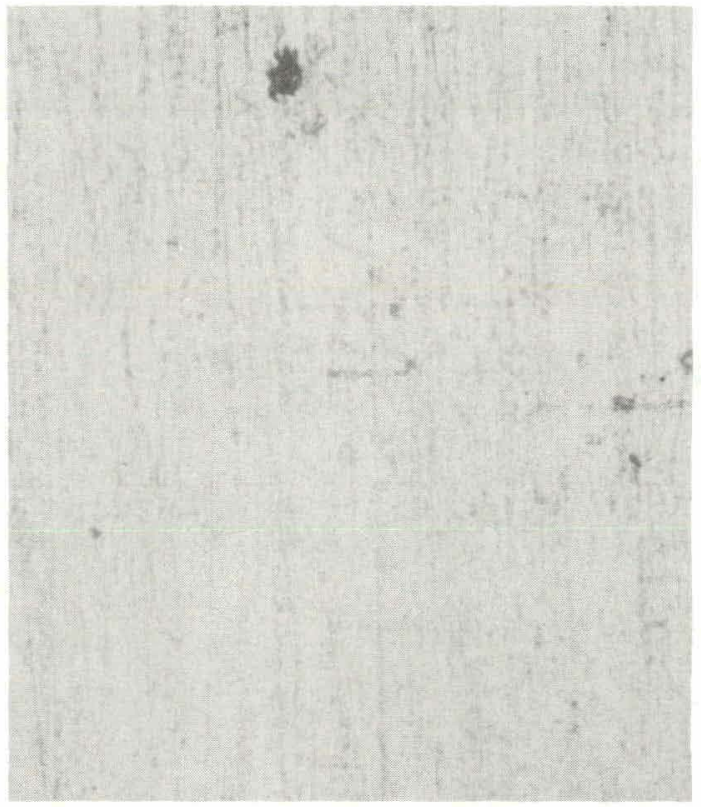

(c) Side B, before.

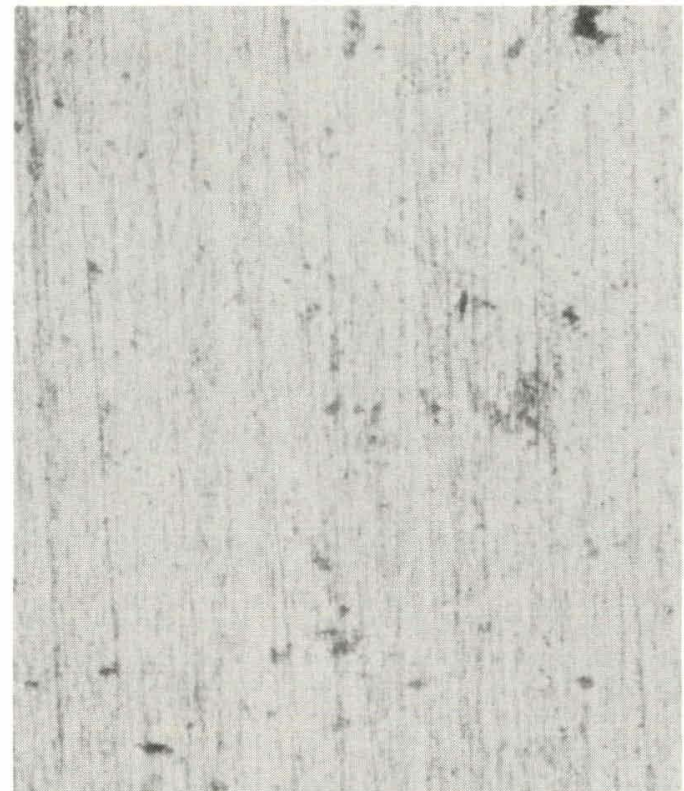

(b) Side A, after.

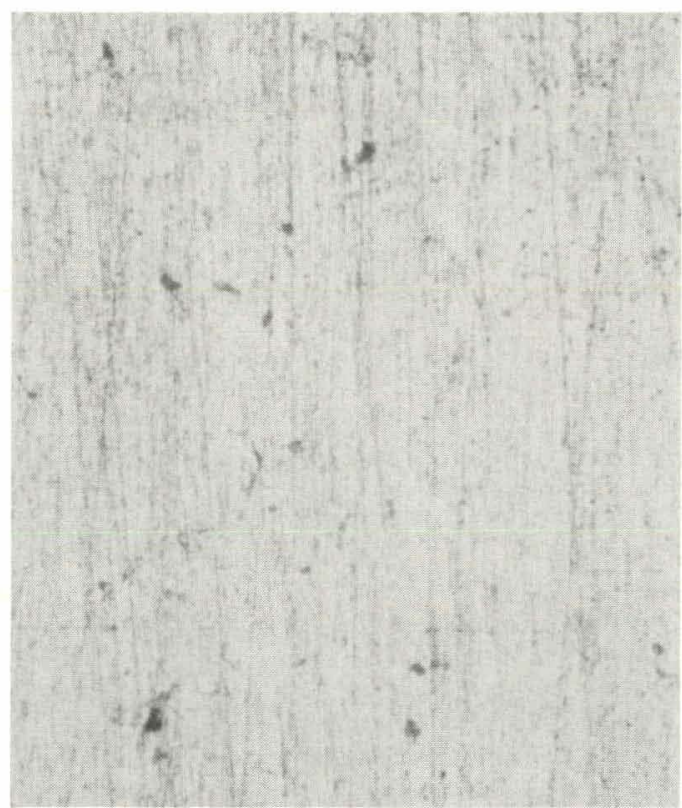

(d) Side B, after.

Figure 10. STAINLESS STEEL; DEARBORN-537 TREATMENT (21 DAYS AT $84^{\circ} \mathrm{F}$ ). (50X) 
The weight changes measured for the metal types tested were negligible and hardly measurable to the nearest $0.1 \mathrm{mg}$. A photographic evaluation technique was used to help evaluate the degree of corrosion by observing fiducial marks on the metal surfaces of the test coupons. The degree of corrosion protection was so effective with this treatment that changes in the surface microfinish of the coupons before and after exposure were hardly perceptible at 50X.

Analytical data obtained on the treated water using the DOE-patented blend of corrosion inhibitors are summarized in Table 4.

Photomicrographs of the metal coupon surfaces before and after exposure to the $\mathrm{Y}-12$ Plant, DOE-patented blend of corrosion inhibitors after a 21 - $\mathrm{d}$ exposure at $29^{\circ} \mathrm{C}\left(84^{\circ} \mathrm{F}\right)$ are presented in Figures 11 through 16.

Dearborn-537, Stagnant-Water, Air-Exposure Tests-Corrosion data on the commercial water-treatment formulation of interest, Dearborn-537, a proprietary blend of nitrite-borate-silicate corrosion inhibitors, were obtained to evaluate the question as to whether it would be more advantageous to drain the centrifuge machine cooling water from the units over an assummed 1-month, downtime, shop-repair period or let the cooling water remain stagnant in the machine during this period. The six different types of weighed metal coupons: copper, steel, brass, stainless steel, and two different aluminum alloys (in duplicate), were treated for $4 \mathrm{~d}$ with the Dearborn-537 at $29^{\circ} \mathrm{C}\left(84^{\circ} \mathrm{F}\right)$ at a controlled-water-flow rate of $95 \mathrm{~mL} / \mathrm{s}(1.5 \mathrm{gpm})$, equivalent to a water velocity of $185 \mathrm{~mm} / \mathrm{s}$ ( 0.61 linear $\mathrm{fps}$ ), to establish a protective inhibitor film on the metal surfaces. One side of the pilot-plant system was then drained of the Dearborn-537 solution and exposed to moisture-laden air in the PVC piping at ambient temperature for $28 \mathrm{~d}$, and the other side of the system was exposed to the stagnant Dearborn-537 inhibitor solution for $28 \mathrm{~d}$. Visual examination of the six different types of metal coupons showed that the surfaces of the two types of aluminum alloy coupons, 3003 and 6061 , that had been exposed to the moist air for $28 \mathrm{~d}$ oxidized much more severely than the companion aluminum alloy coupons immersed in the stagnant, noncirculating, Dearborn-537 solution.

A summiary of weight-change data for the six different types of metal coupons used in the 28-d moist-air test and in the noncirculating Dearborn-537-solution test is presented in Table 5.

Table 4

Photomicrographs of the metal coupon surfaces before and after applying the film-forming treatment at $29^{\circ} \mathrm{C}\left(84^{\circ} \mathrm{F}\right)$ and exposing for $28 \mathrm{~d}$ to moistureladen air at $25^{\circ} \mathrm{C}\left(77^{\circ} \mathrm{F}\right)$ are presented in Figures 17 through 22. As shown in Figures 17 and 18, the surfaces of the aluminum alloys 6061-T6 and 3003-H1 were highly discolored after moist-air exposure resulting from the formation of a thin, grayish-white discontinuous, nonuniform oxidation

\begin{tabular}{l} 
ANALYSIS OF TREATED WATER FROM \\
DOE-PATENTED BLEND OF \\
CORROSION INHIBITORS \\
\hline pH \\
Total Organic Carbon (ppm) \\
Total Dissolved Solids (ppm) \\
Dissolved Boron (ppm as B) \\
Dissolved Silicon (ppm as $\mathrm{SiO}_{2}$ ) \\
Dissulved Nitite (ppm as $\mathrm{NO}_{2}$ ) \\
\hline
\end{tabular}




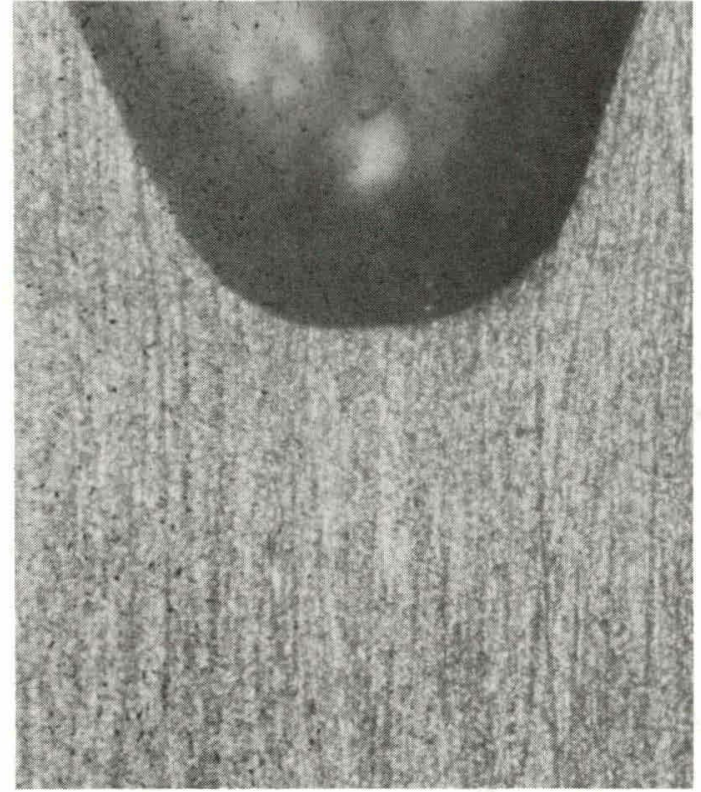

(a) Side A, before.

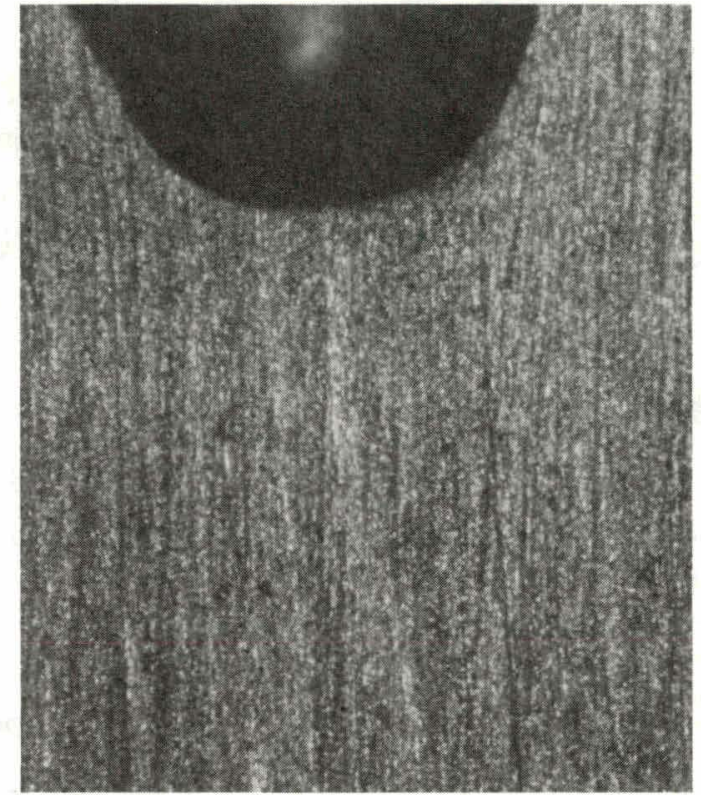

(b) Side A, after.

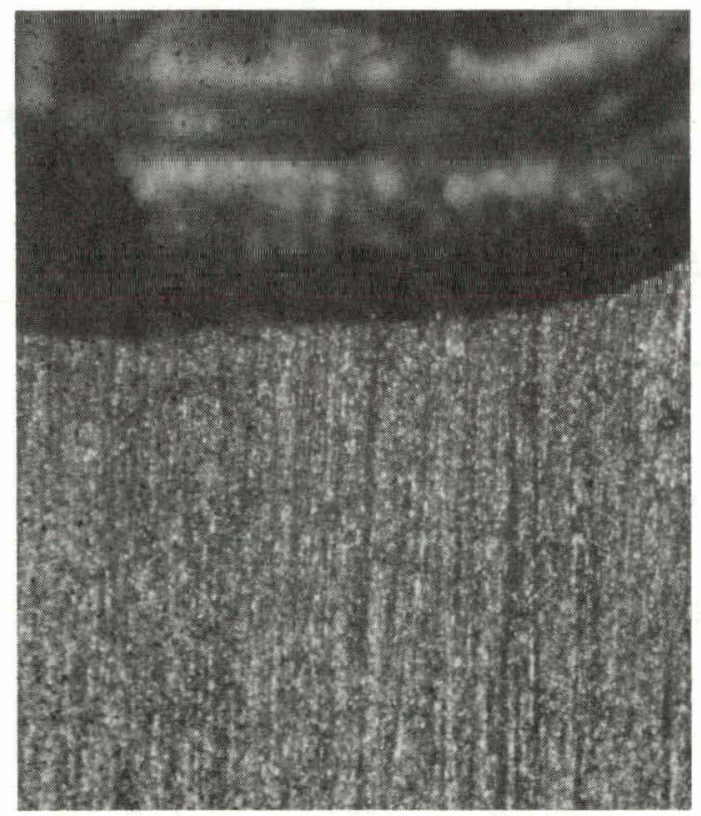

(c) Side B, before.

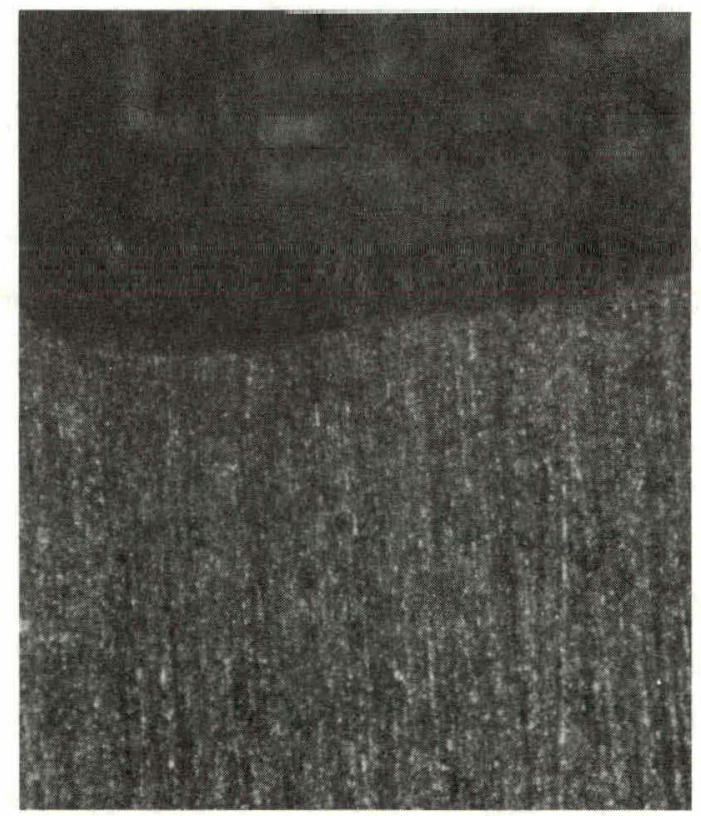

(d) Side B, after.

Figure 11. ALUMINUM ALLOY 3003-H1; Y-12 NITRITE-BORATE-SILICATE TREATMENT (21 DAYS AT $84^{\circ} \mathrm{F}$ ). (50X) 


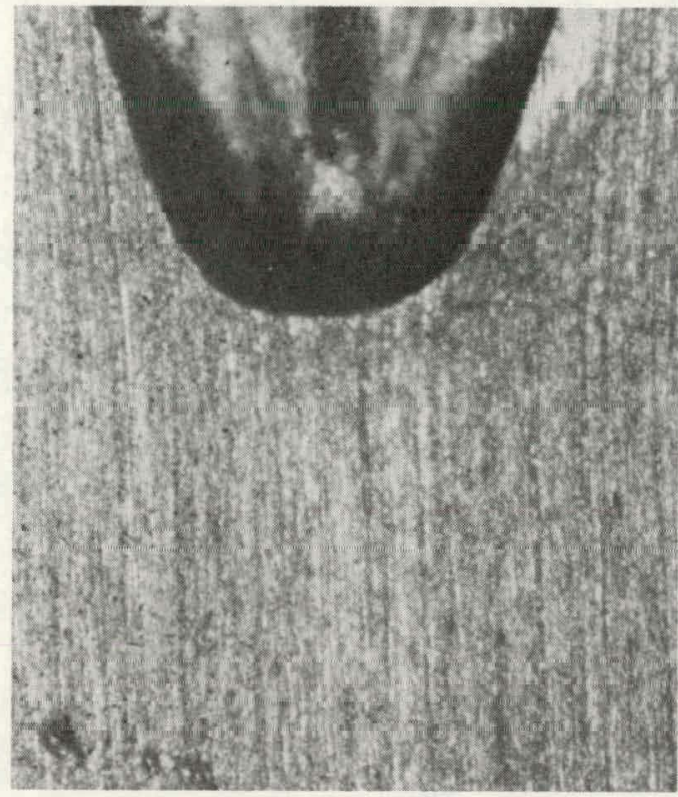

(a) Side A, before.

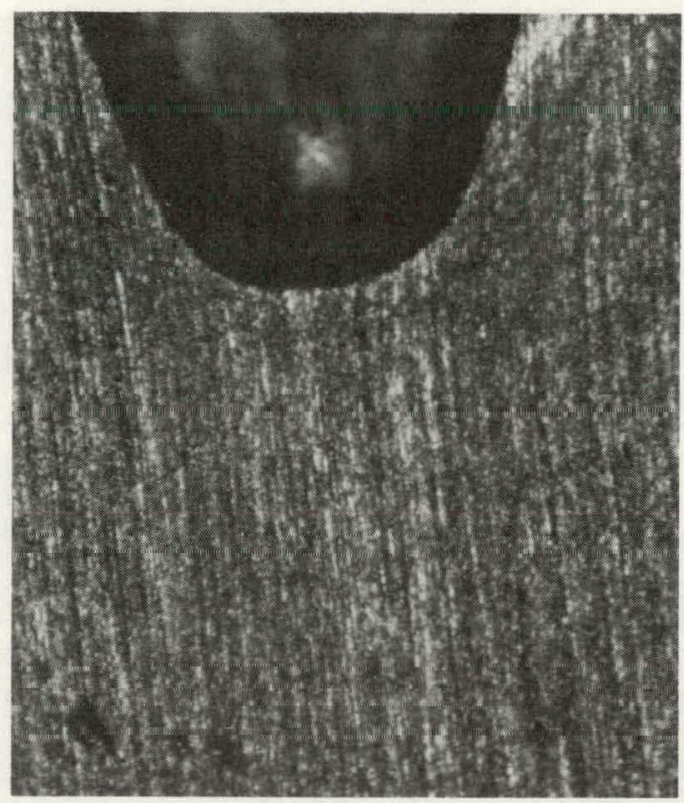

(b) Side A, after

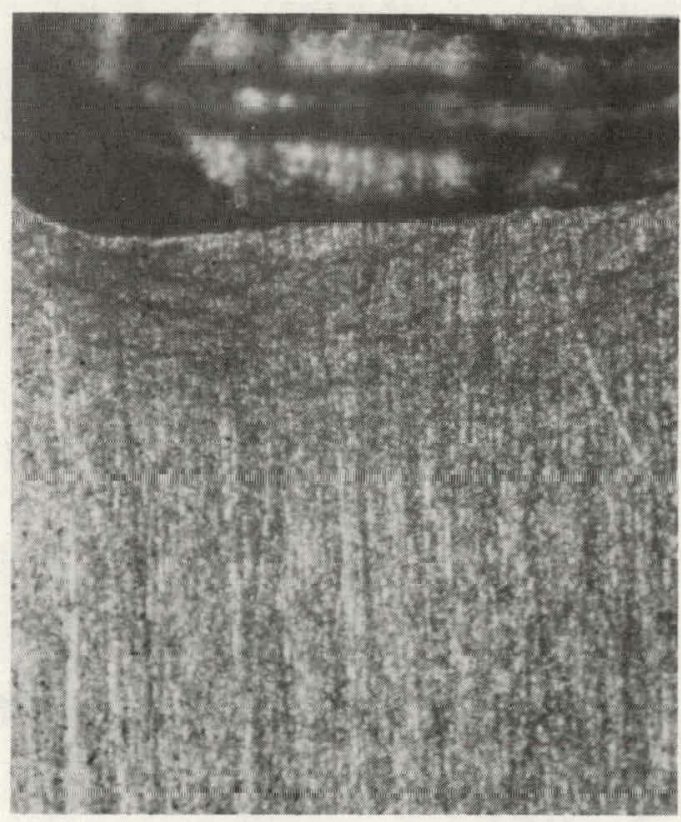

(c) Side B, before.

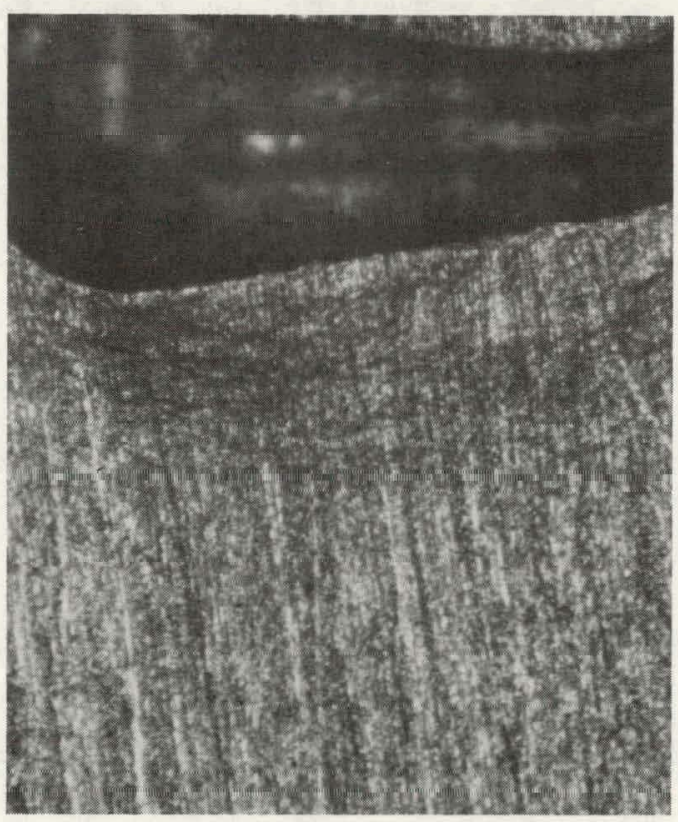

(d) Side B, after.

Figure 12. ALUMINUM ALLOY 6061-T6; Y-12 NITRITE-BORATE-SILICATE TREATMENT (21 DAYS AT $\left.84^{\circ} \mathrm{F}\right)$. (50X) 


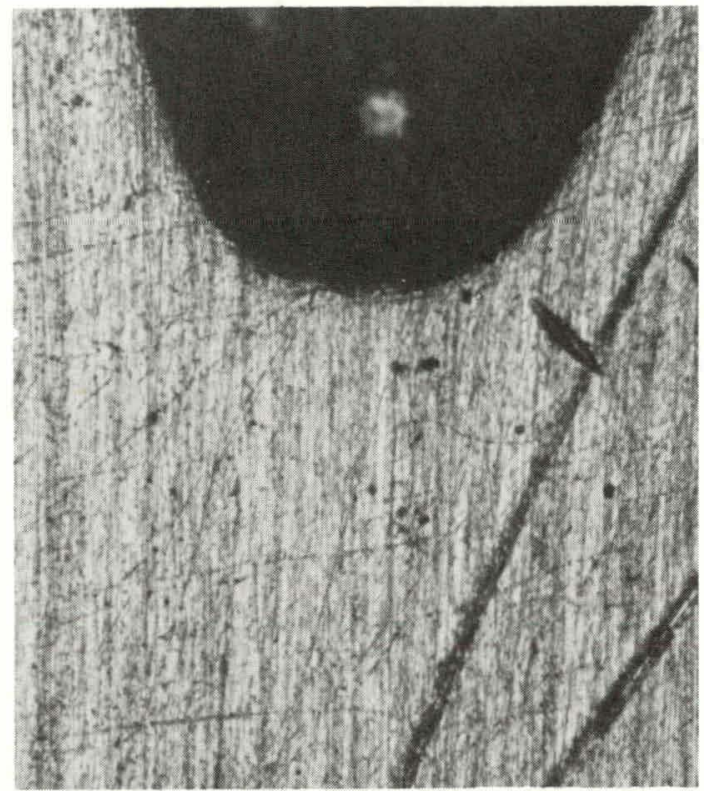

(a) Side A, before.

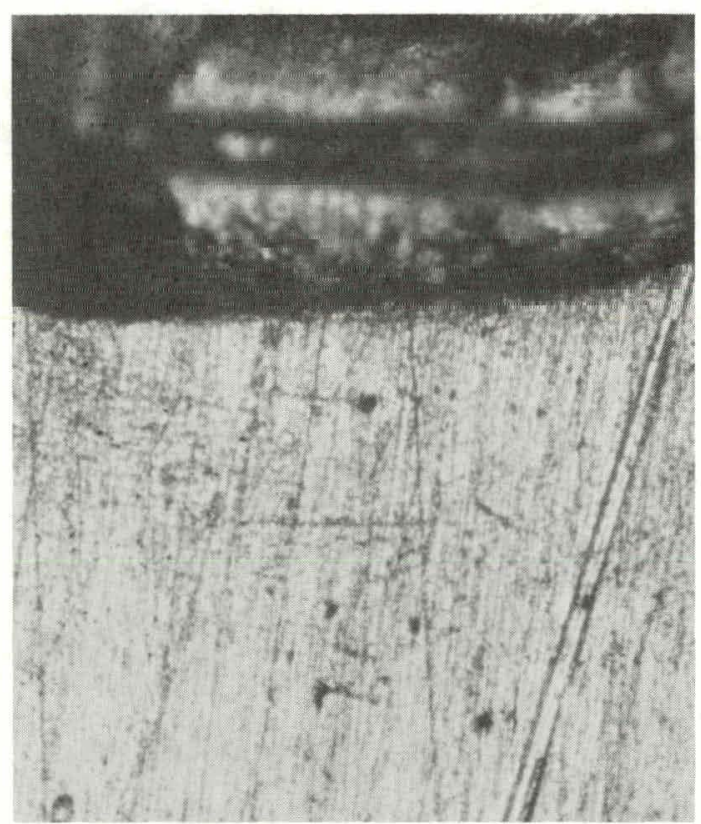

(c) Side B, before.

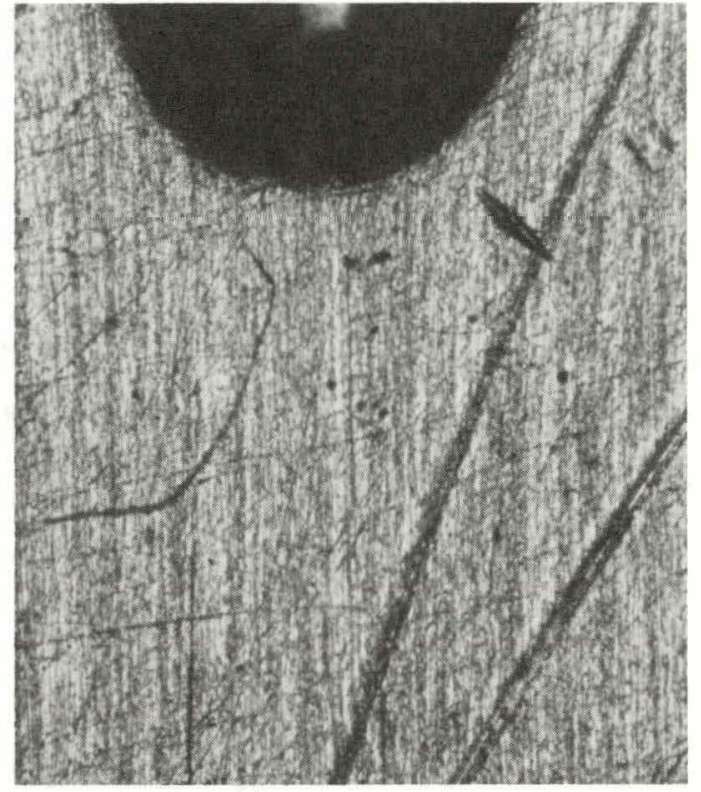

(b) Side A, after.

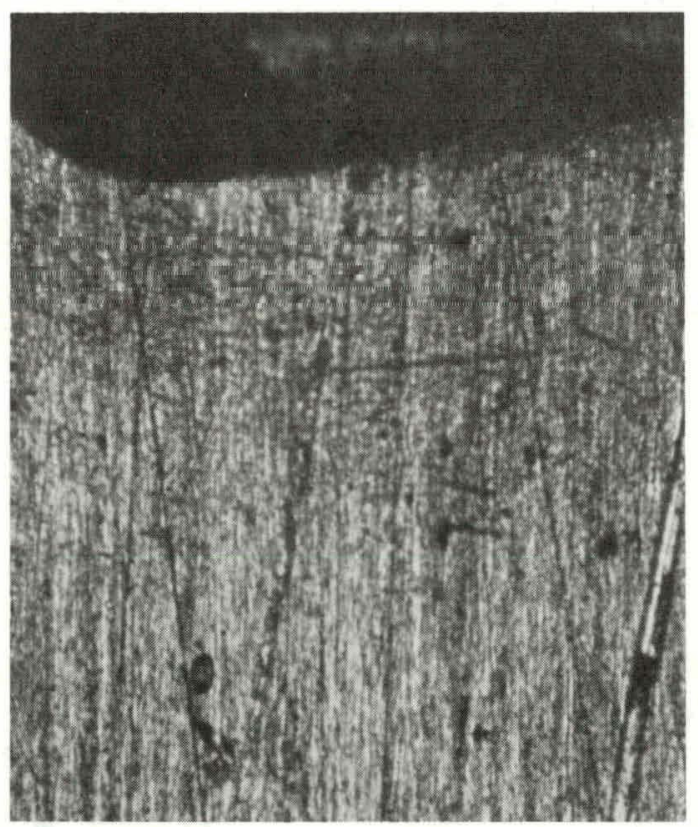

(d) Side B, after.

Figure 13. COPPER; Y-12 NITRITE-BORATE-SILICATE TREATMENT (21 DAYS AT $84^{\circ} \mathrm{F}$ ). (50X) 


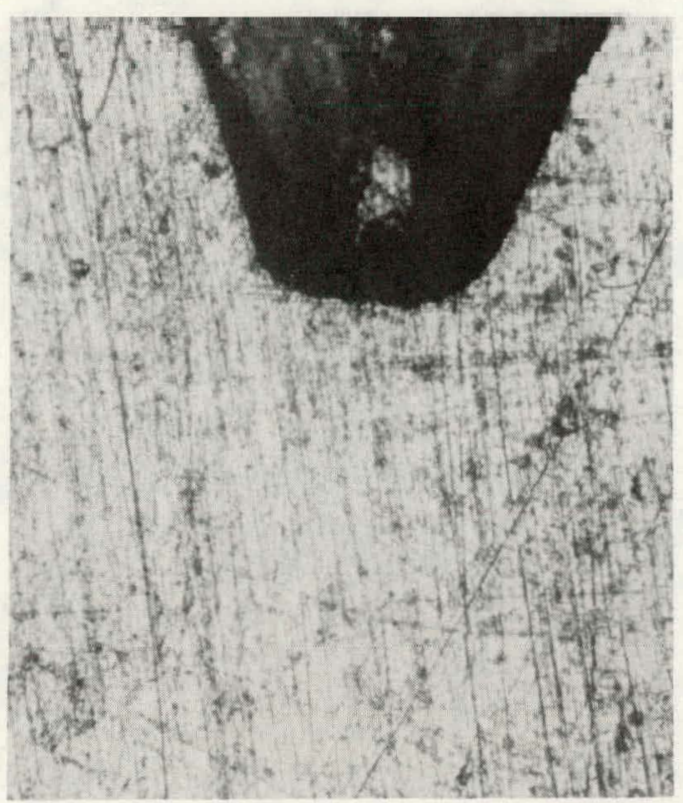

(a) Side A, before.

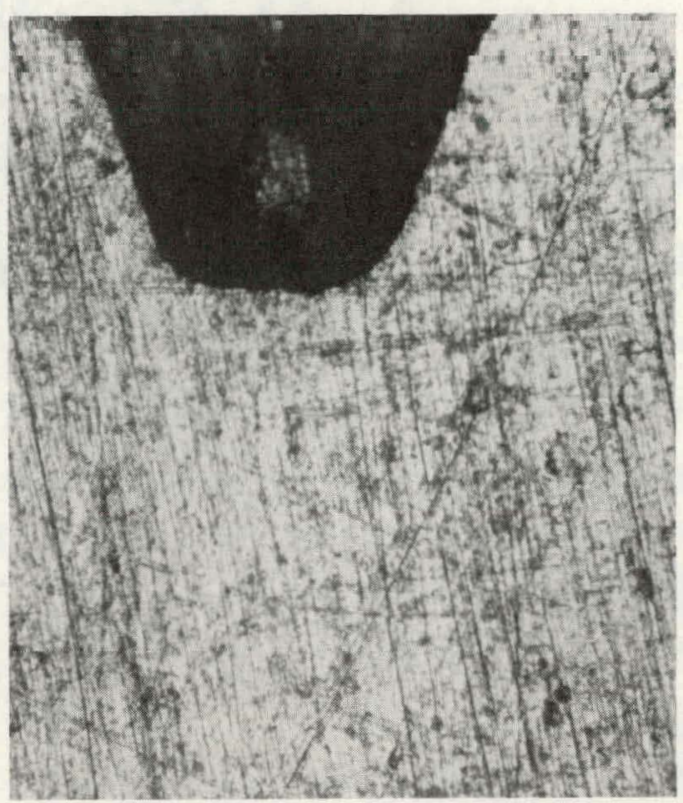

(b) Side A, after.

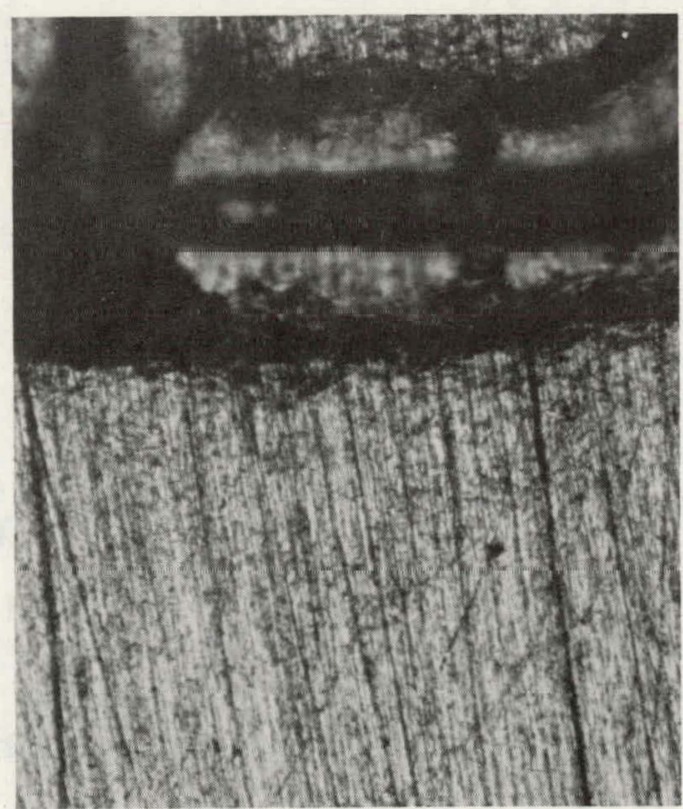

(c) Side B, before.

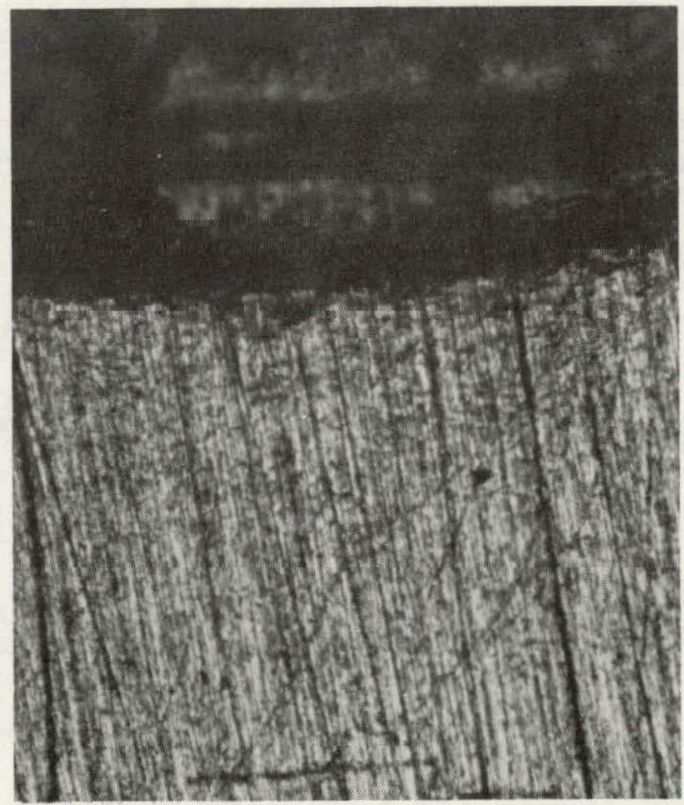

(d) Side B, after.

Figure 14. MUNTZ METAL; Y-12 NITRITE-BORATE-SILICATE TREATMENT (21 DAYS AT $84^{\circ}$ F). (50X) 


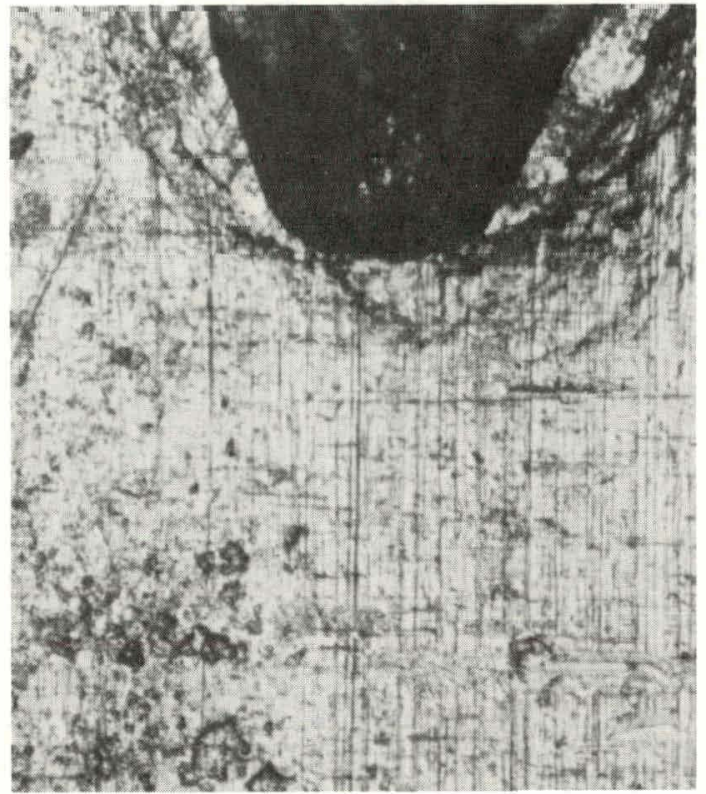

(a) Side A, before,

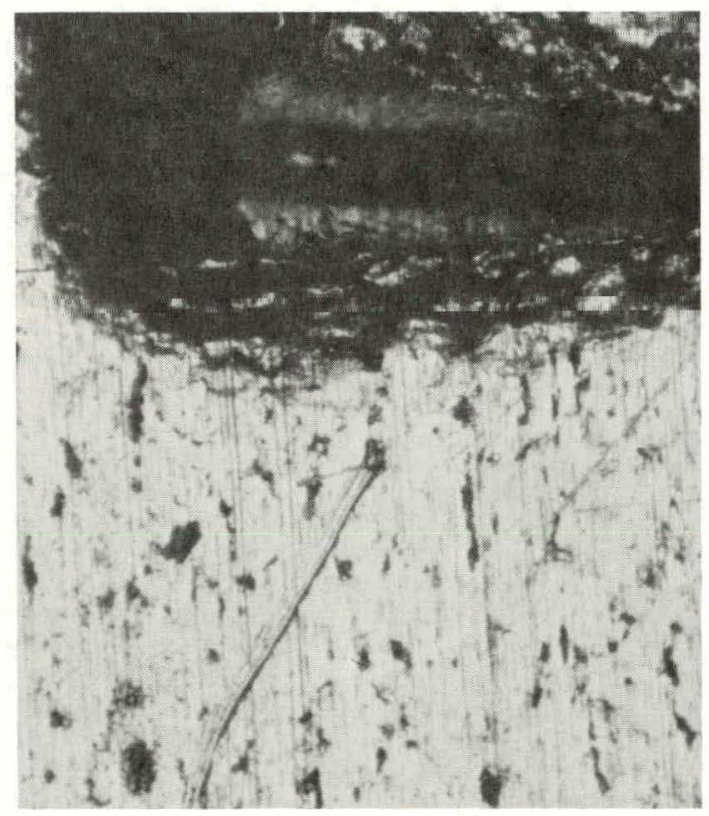

(c) Side B, before.

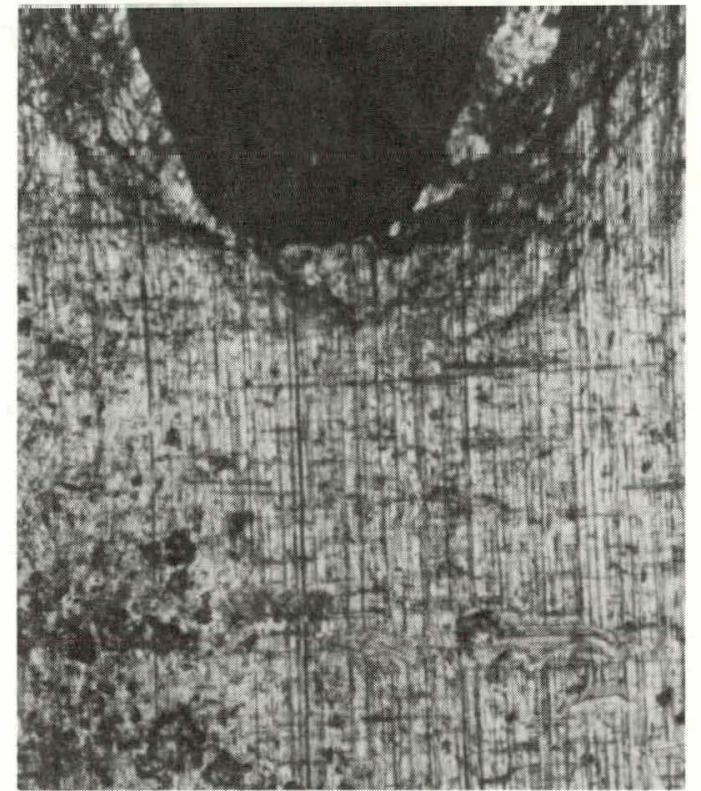

(b) Side A, after.

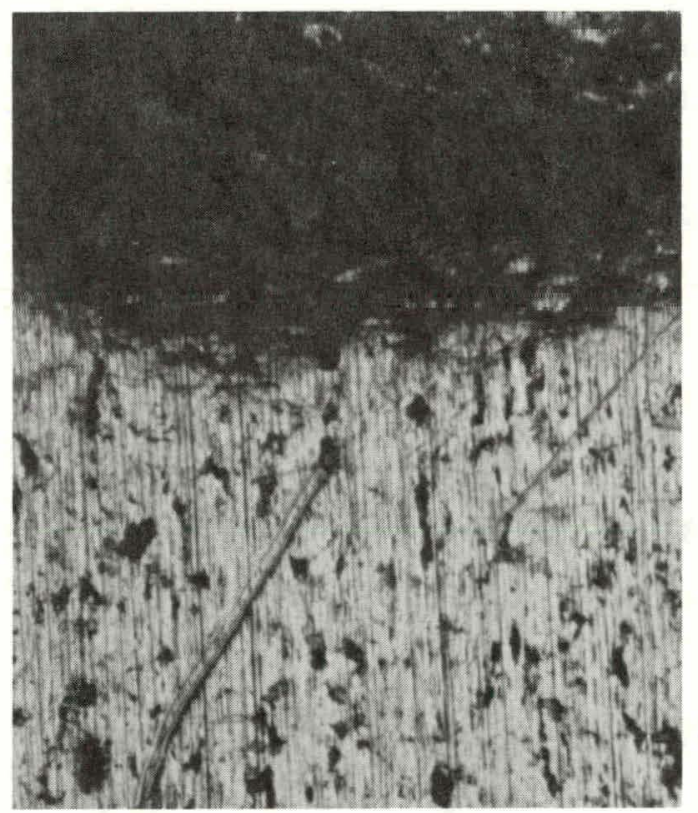

(d) Side B, after.

Figure 15. STEEL; Y-12 NITRITE-BORATE-SILICATE TREATMENT (21 DAYS AT $84^{\circ} \mathrm{F}$ ). (50X) 


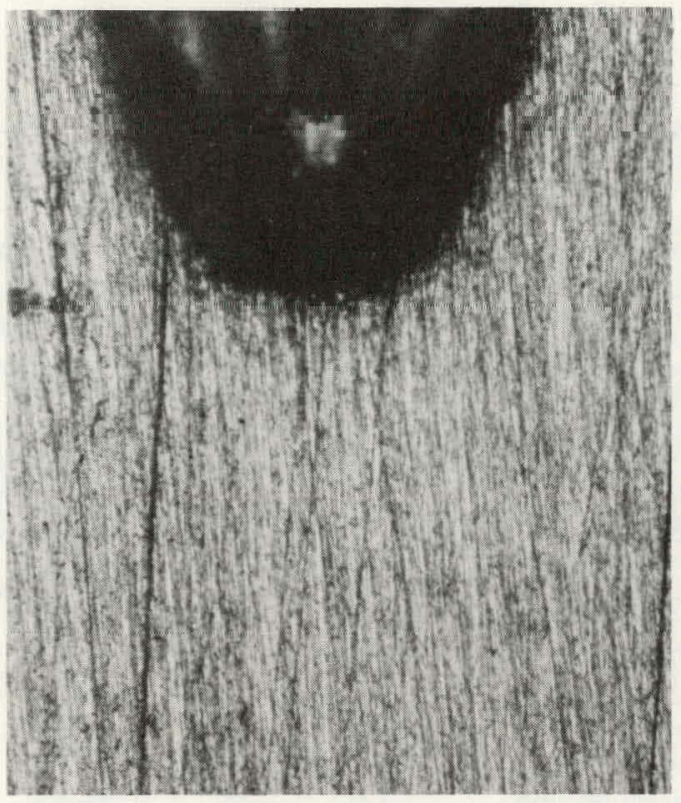

(a) Side A, before.

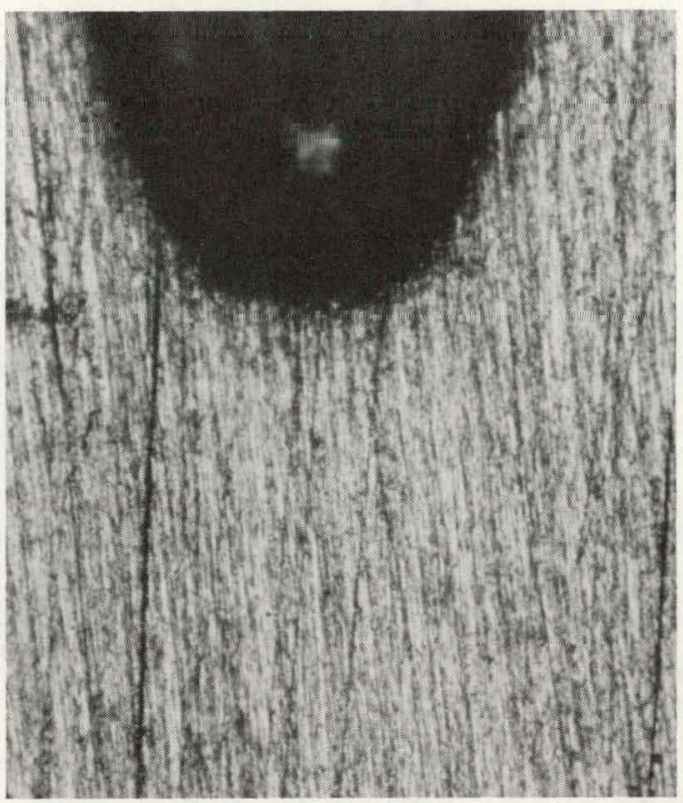

(b) Side A, after.

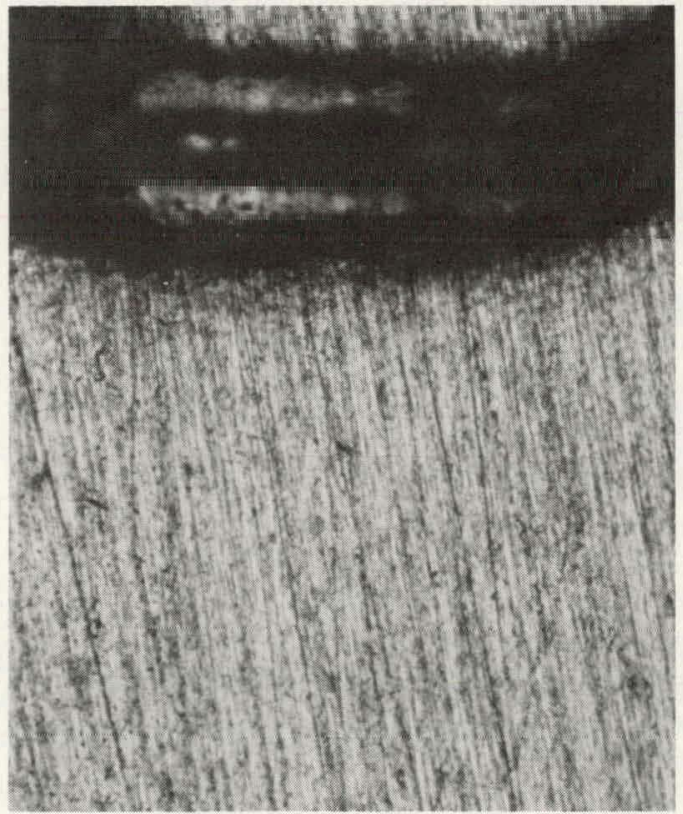

(c) Side B, before.

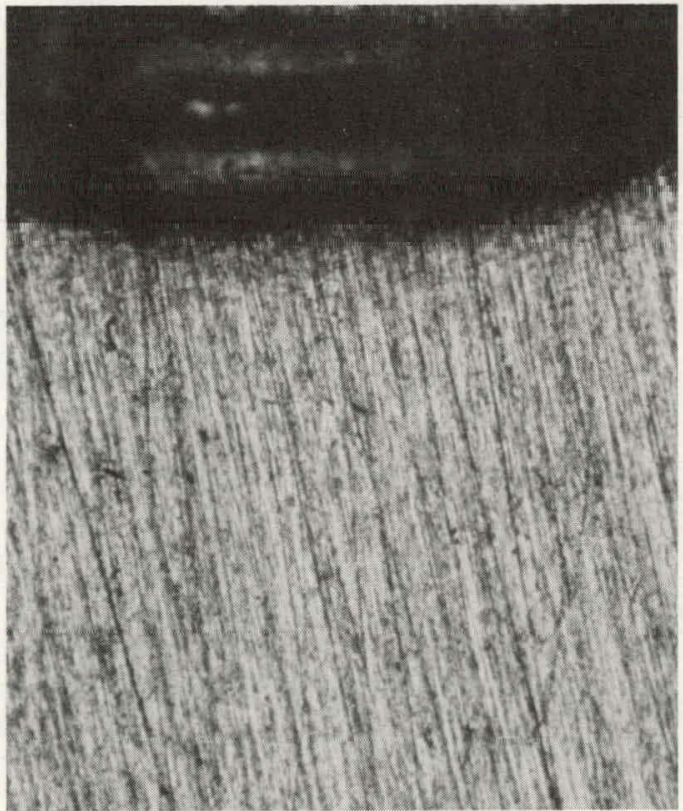

(d) Side B, after.

Figure 16. STAINLESS STEEL; Y-12 NITRITE-BORATE-SILICATE TREATMENT (21 DAYS AT $84^{\circ} \mathrm{F}$ ). (50X) 
Table 5

CORROSION-TEST-COUPON WEIGHT CHANGES ACCOMPANYING DEARBORN-537, STAGNANT-WATER, AIR-EXPOSURE TESTS

\begin{tabular}{|c|c|c|c|c|}
\hline \multirow[b]{2}{*}{ Specimen } & \multirow[b]{2}{*}{ Metal Type } & \multicolumn{3}{|c|}{ Weight (g) } \\
\hline & & Initial & Final & Change \\
\hline \multicolumn{5}{|c|}{ After 28-Day Moist-Air Exposure } \\
\hline$M-5$ & Aluminum Alloy $3003-\mathrm{H} 1$ & 4.9862 & 4.9933 & +0.0071 \\
\hline A-5 & Aluminum Alloy 6061-T6 & 6.0836 & 6.0848 & +0.0012 \\
\hline $60 N$ & Steel & 13.6788 & 13.6796 & +0.0008 \\
\hline AA-6 & Copper & 21.2149 & 21.2155 & +0.0006 \\
\hline BM-5 & Muntz Metal (60\% copper, $40 \%$ zinc) & 19.4146 & 19.4154 & +0.0008 \\
\hline SS-5 & Stainless Steel & 17.2129 & 17.2130 & +0.0001 \\
\hline \multicolumn{5}{|c|}{ After 28-Day Exposure to Stagnant Dearborn Solution } \\
\hline$M-4$ & Aluminum Alloy $3003-\mathrm{H} 1$ & 4.9826 & 4.9832 & +0.0006 \\
\hline$A-4$ & Aluminum Alloy 6061-T6 & 6.1930 & 6.1935 & +0.0005 \\
\hline $46 \mathrm{~N}$ & Steel & 13.6884 & 13.6887 & +0.0003 \\
\hline AA-5 & Copper & 21.3092 & 21.3098 & +0.0006 \\
\hline BM-4 & Muntz Metal (60\% copper, $40 \%$ zinc) & 19.8120 & 19.8128 & +0.0008 \\
\hline SS-4 & Stainless Steel & 17.1469 & 17.1472 & +0.0003 \\
\hline
\end{tabular}

film, presumably aluminum oxide hydrate $\left(\mathrm{Al}_{2} \mathrm{O}_{3} \cdot \mathrm{H}_{2} \mathrm{O}\right)$. This discontinuous surface film was not observed on the coupon surfaces of the companion aluminum alloys (6061-T6 and $3003-\mathrm{H} 1$ ) that had been exposed to the stagnant Dearborn-537 water solution after $28 \mathrm{~d}$. Visual microscopic examinations of these surfaces before and after $28 \mathrm{~d}$ of exposure to the stagnant Dearborn-537 solution were also made, but photomicrographs were not taken because these surfaces appeared to be unchanged and identical after exposure as compared with before exposure.

The Dearborn-537 test was made using a 114-L (30-gal) volume of ORGDP sanitary water and Dearborn-537 concentrate. The Dearborn-537 concentrate was diluted with the ORGDP sanitary water in the volume ratio of $1: 100$ as per instructions. An analysis of the Dearborn-537treated water is given in Table 6 .

Table 6

ANALYSIS OF DEARBORN-537-TREATED WATER USED FOR STAGNANT-WATER CORROSION TEST

Zimmite ZC-404 Corrosion Test Corrosion-rate data on another water-treatment formulation of interest, Zimmite ZC-404, (e) were obtained after a 21-d exposure

\begin{tabular}{lc}
\hline $\mathrm{pH}$ & 10.1 \\
Total Hardness (ppm as $\left.\mathrm{CaCO}_{3}\right)$ & 137 \\
Boron (ppm as $\mathrm{B})$ & 115 \\
Nitrite $\left(\mathrm{ppm}\right.$ as $\mathrm{NO}_{2}$ ) & 788 \\
Silicate $\left(\mathrm{ppm}\right.$ as $\mathrm{SiO}_{2}$ ) & 117 \\
Chloride $(\mathrm{ppm}$ as $\mathrm{Cl})$ & 31 \\
\hline
\end{tabular}

(e) Zimmite Corporation, Cleveland, Ohio. 


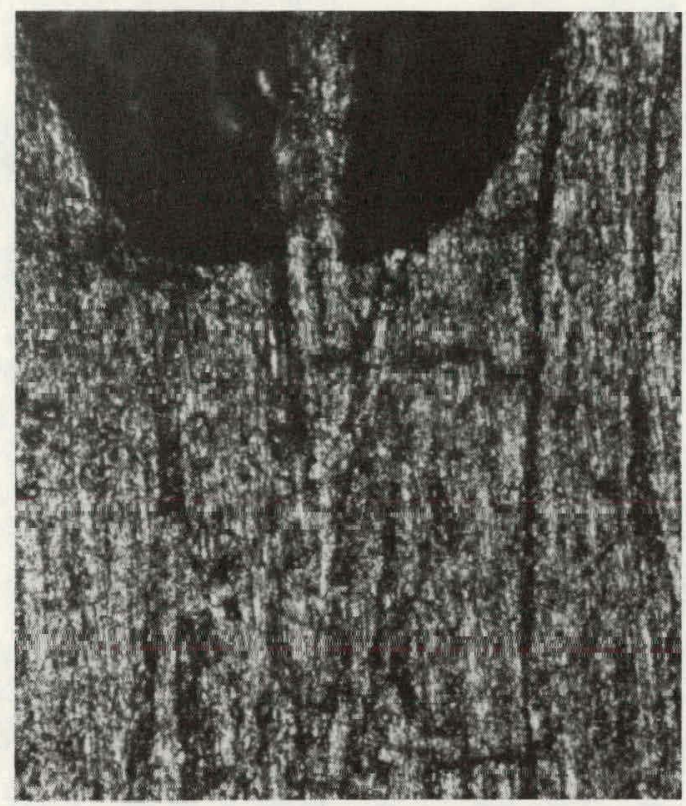

(a) Side A, before.

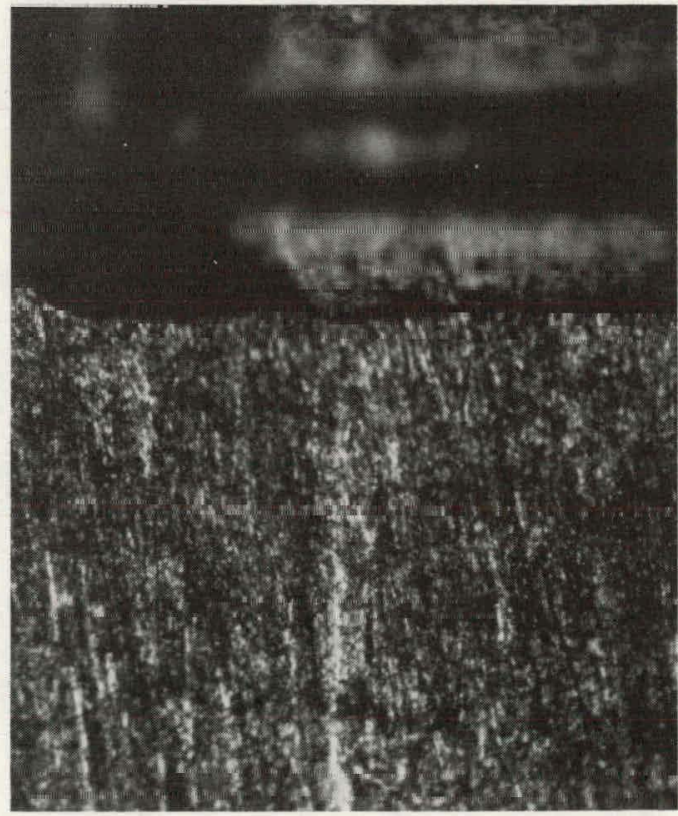

(c) Side B, before.

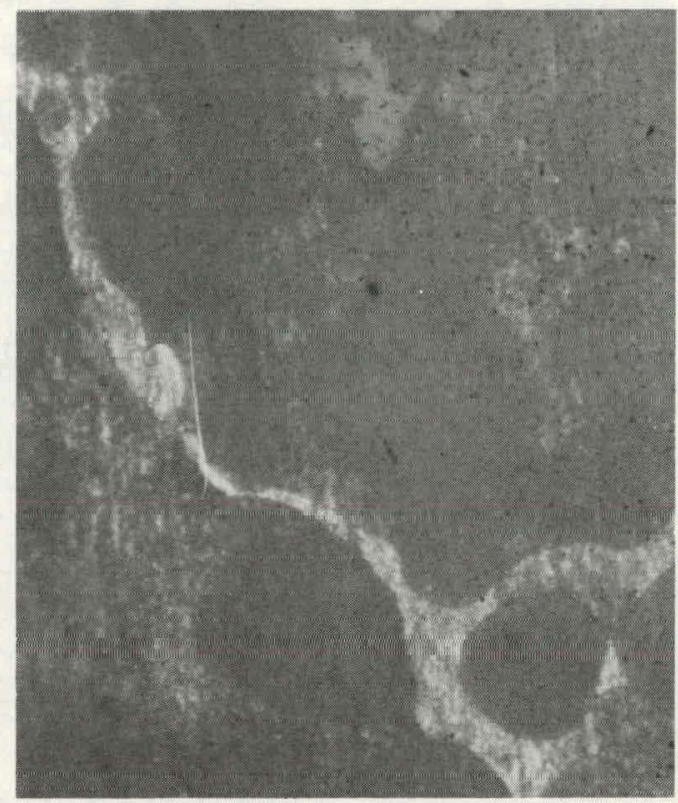

(b) Side A, after.

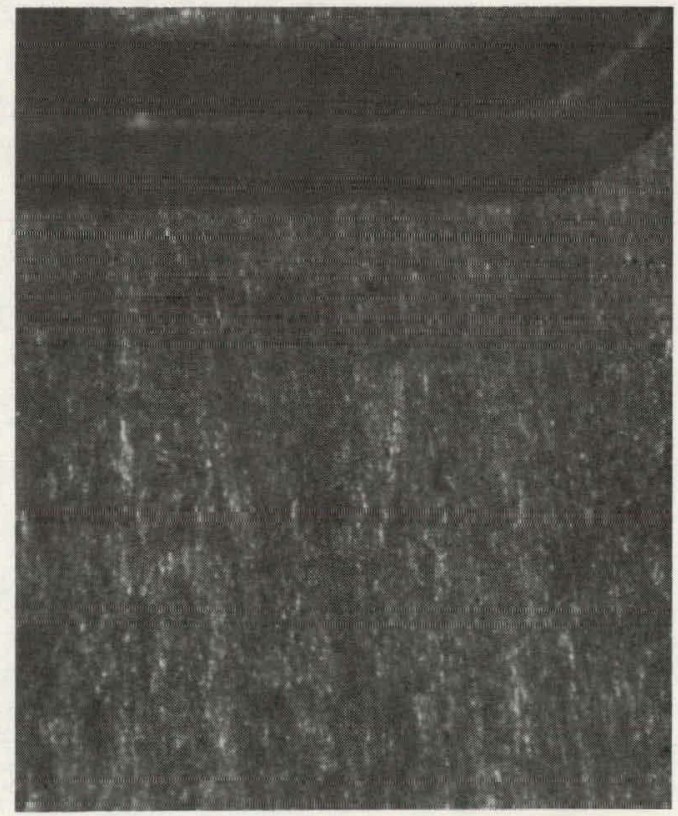

(d) Side B, after.

Figure 17. ALUMINUM ALLOY 3003-H1; DEARBORN-537 TREATMENT (4 DAYS AT $84^{\circ} \mathrm{F}, 28$ DAYS MOIST-AIR EXPOSURE). (50X) 


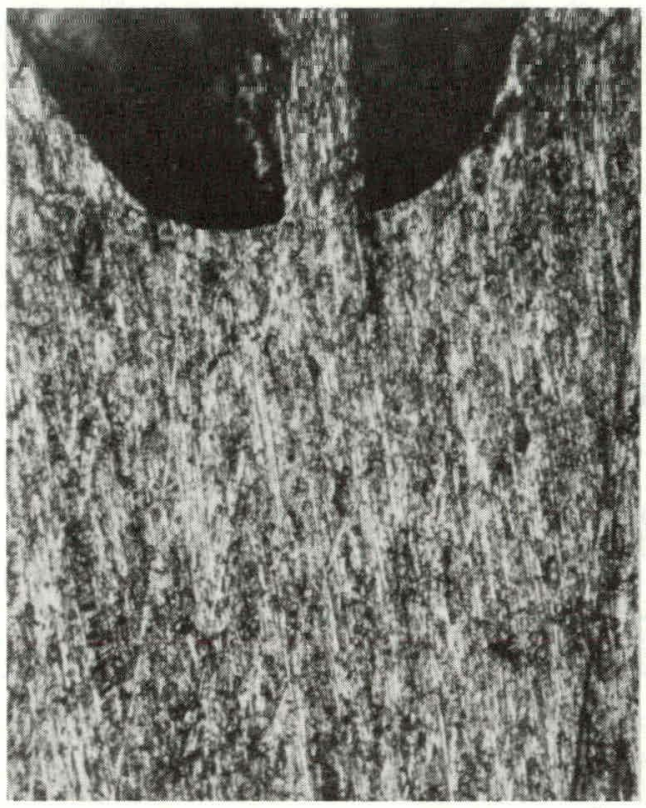

(a) Side A, before.

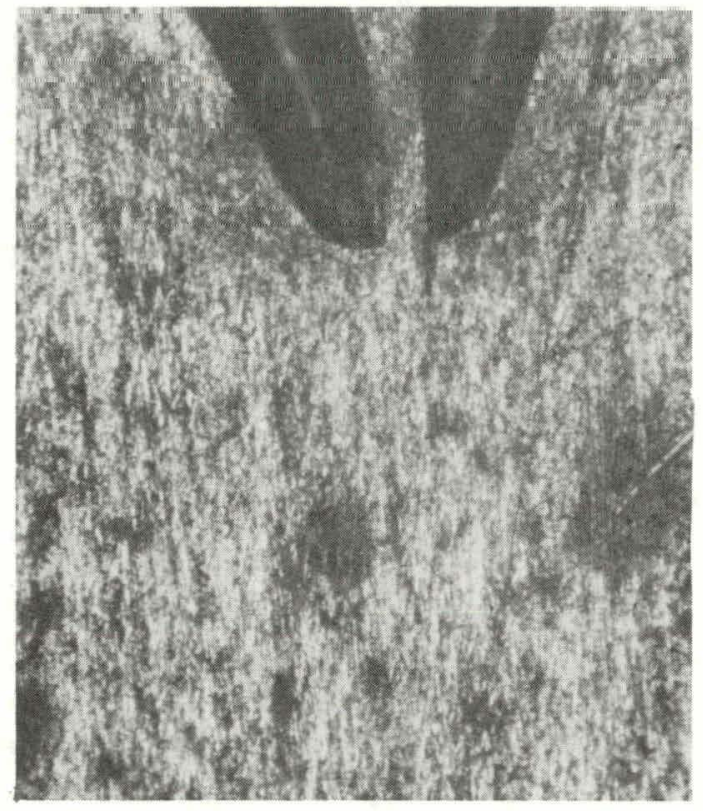

(b) Side $A$, after.

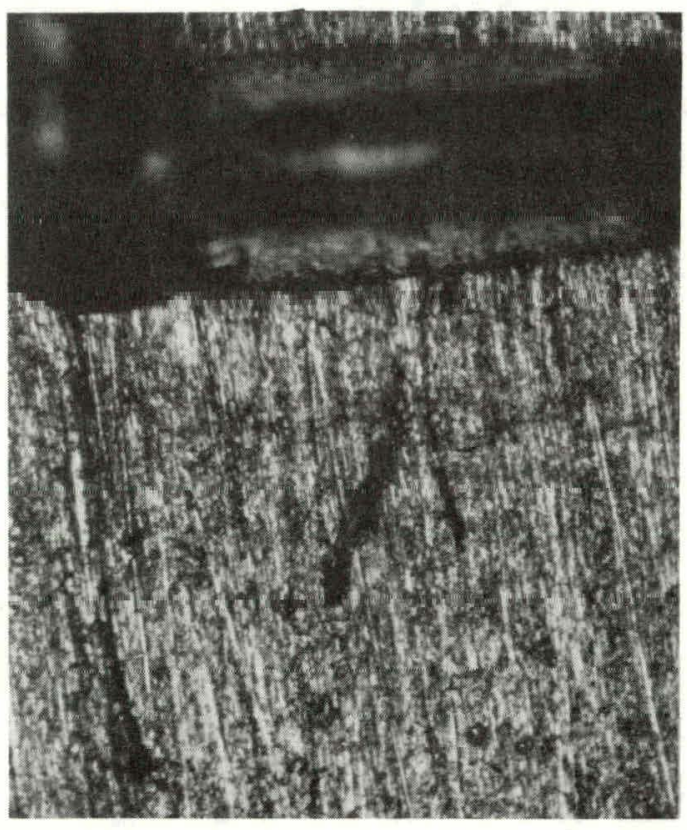

(c) Side B, before.

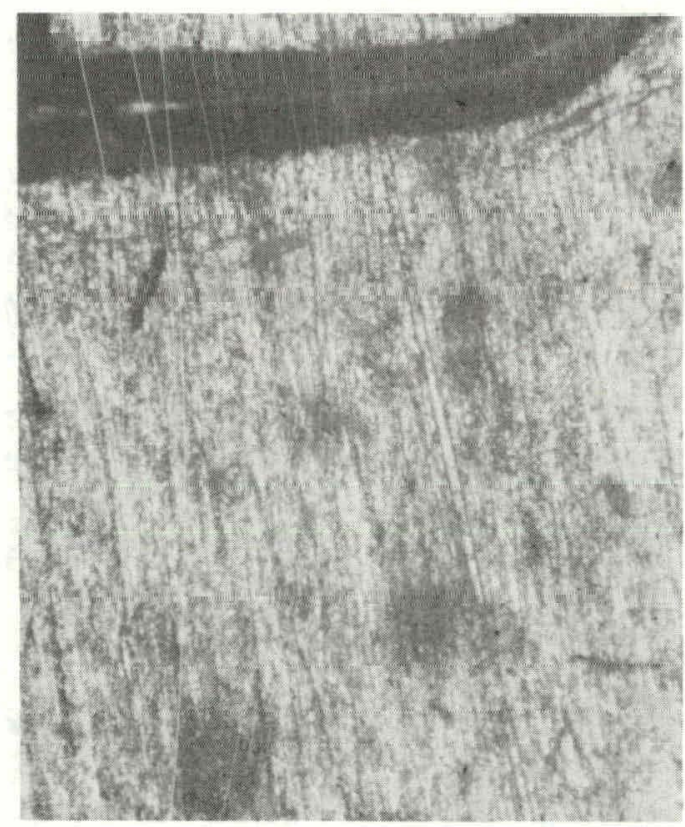

(d) Side B, after.

Figure 18. ALUMINUM ALLOY 6001-T6; DEARBORN-537 TREATMENT (4 DAYS AT 84 ${ }^{\circ}$, 28 DAYS MOIST-AIR EXPOSURE). (50X) 


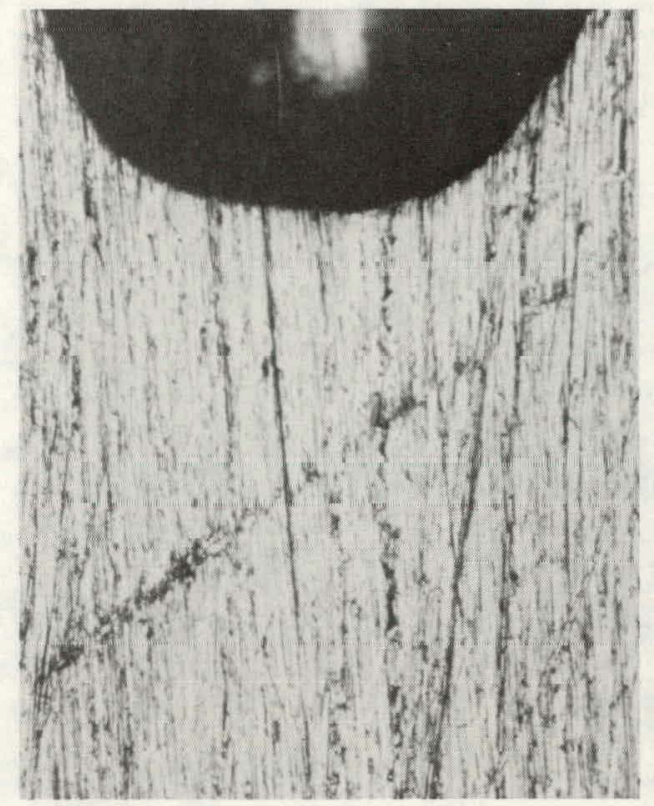

(a) Side $\mathrm{A}$, before.

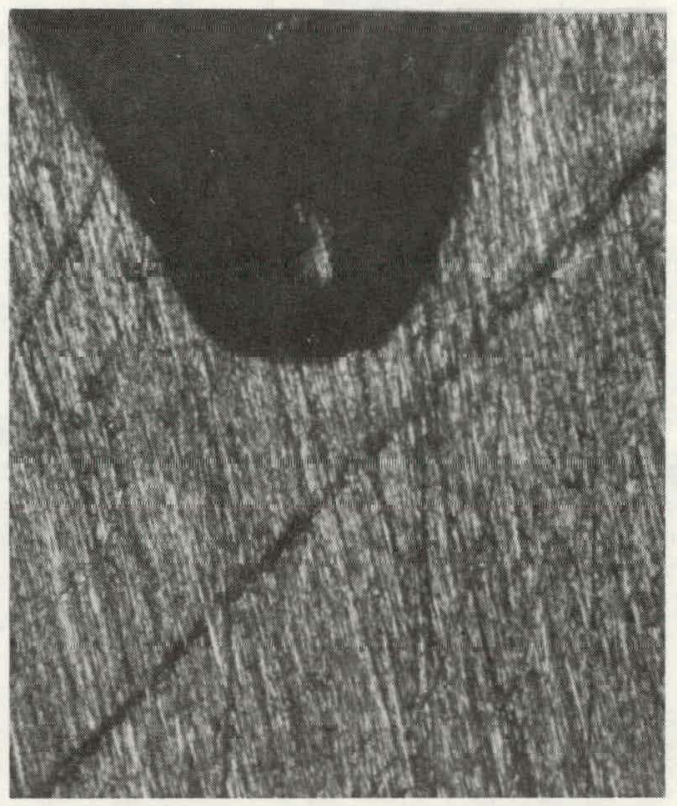

(b) Side A, after.

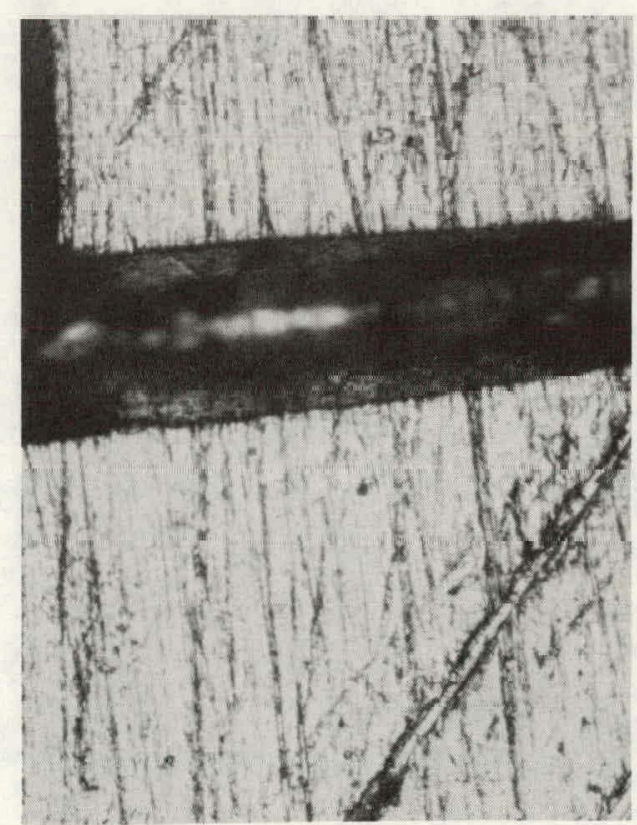

(c) Side B, before.

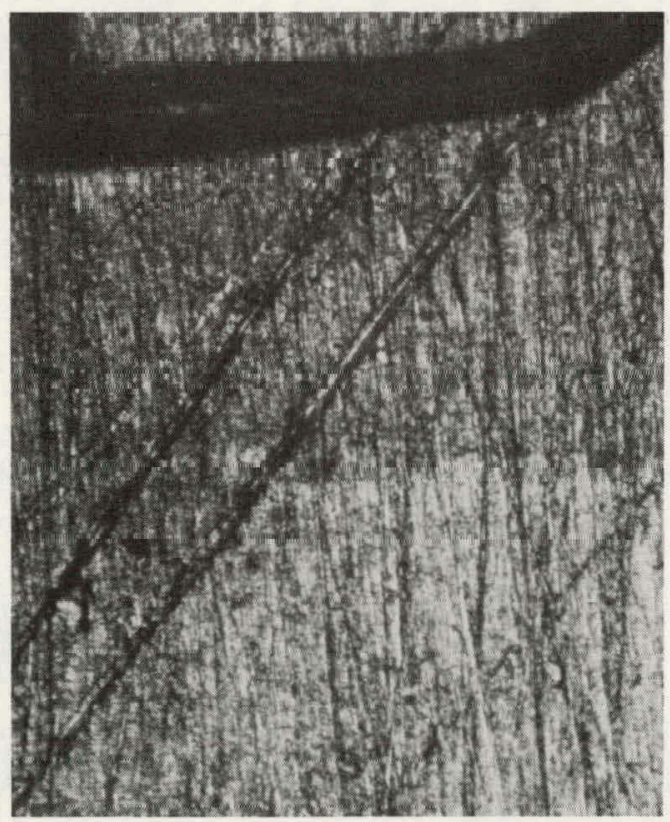

(d) Side B, after.

Figure 19. COPPER; DEARBORN-537 TREATMENT (4 DAYS AT $84^{\circ} \mathrm{F}, 28$ DAYS MOIST-AIR EXPOSURE). (50X) 


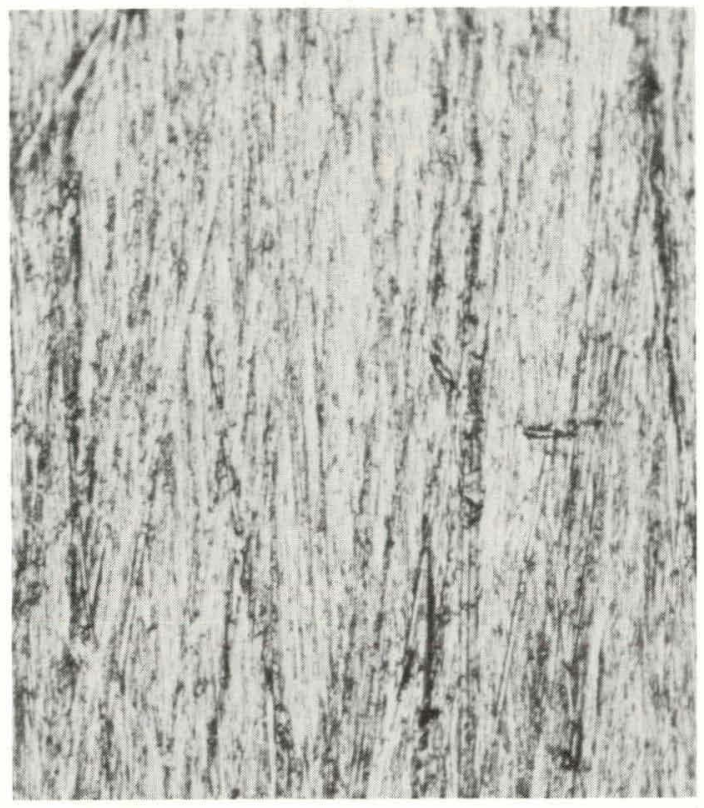

(a) Side A, before.

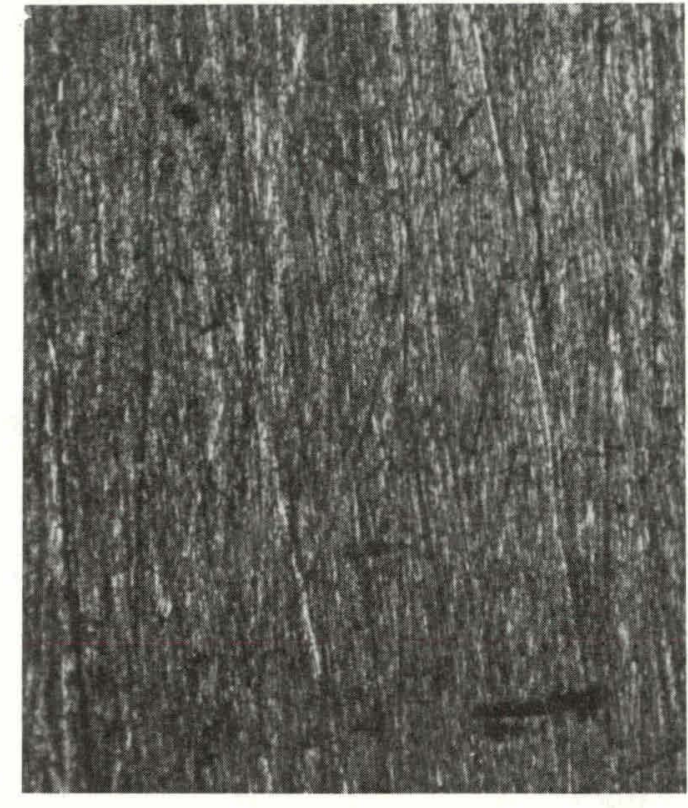

(b) Side A, after.

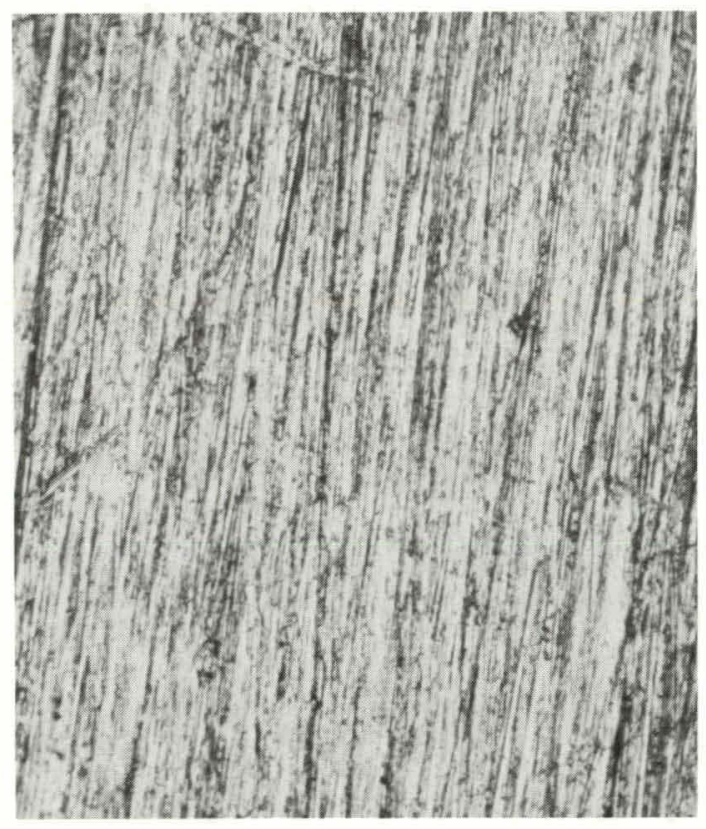

(c) Side B, before.

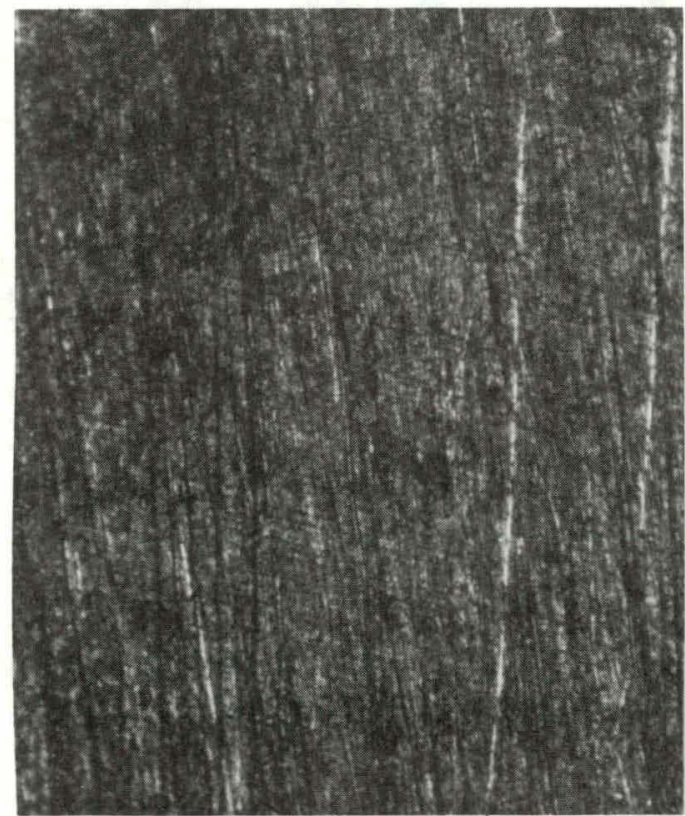

(d) Side B, after.

Figure 20. MUNTZ METAL; DEARBORN-537 TREATMENT (4 DAYS AT $84^{\circ} \mathrm{F}, 28$ DAYS MOIST-AIR EXPOSURE). (50X) 


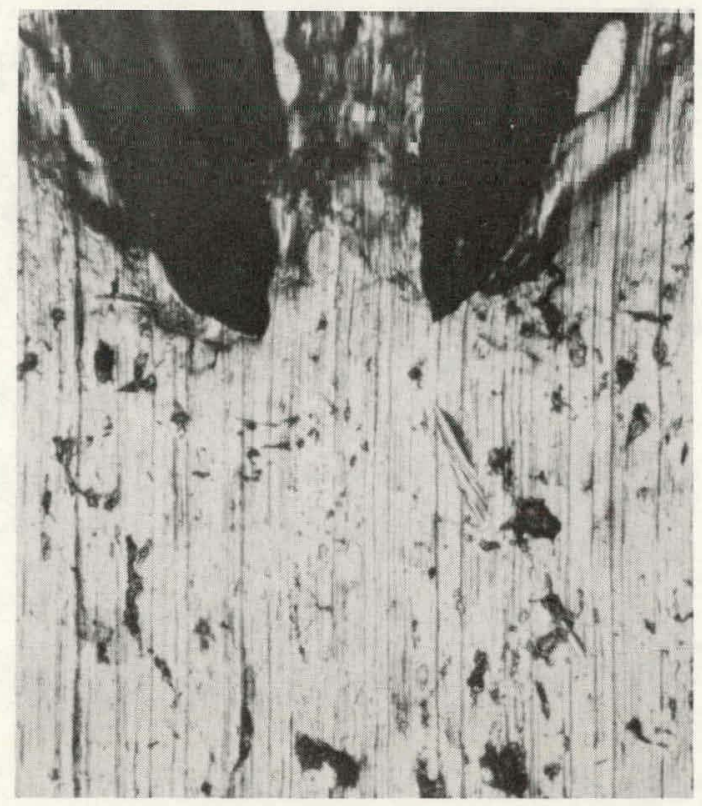

(a) Side A, before.

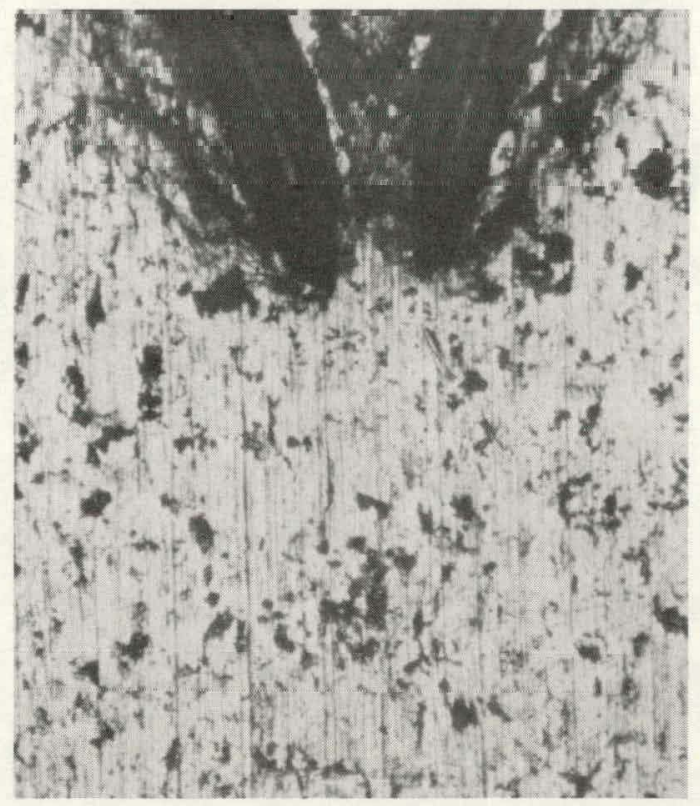

(b) Side A, after.

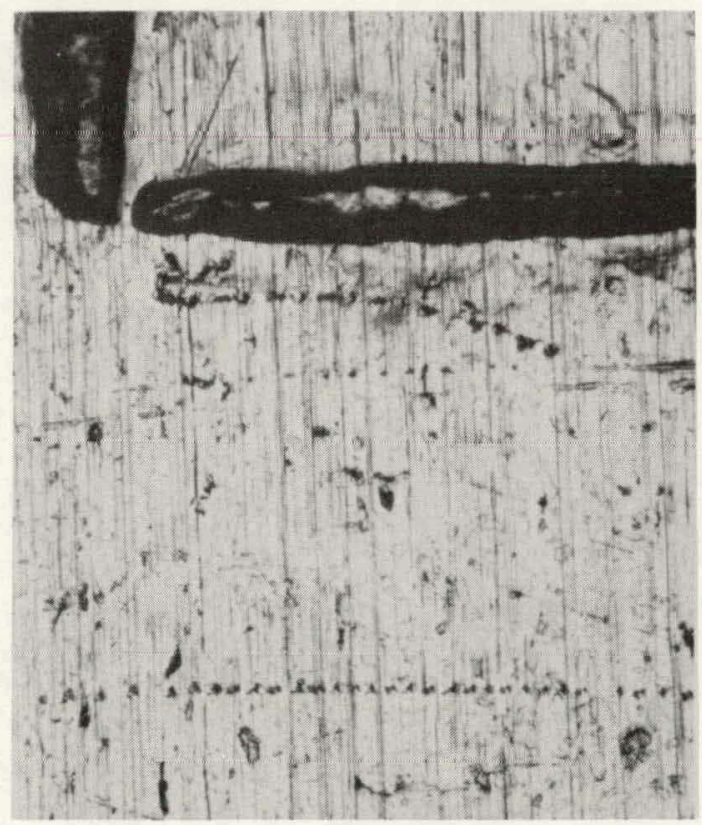

(c) Side B, before.

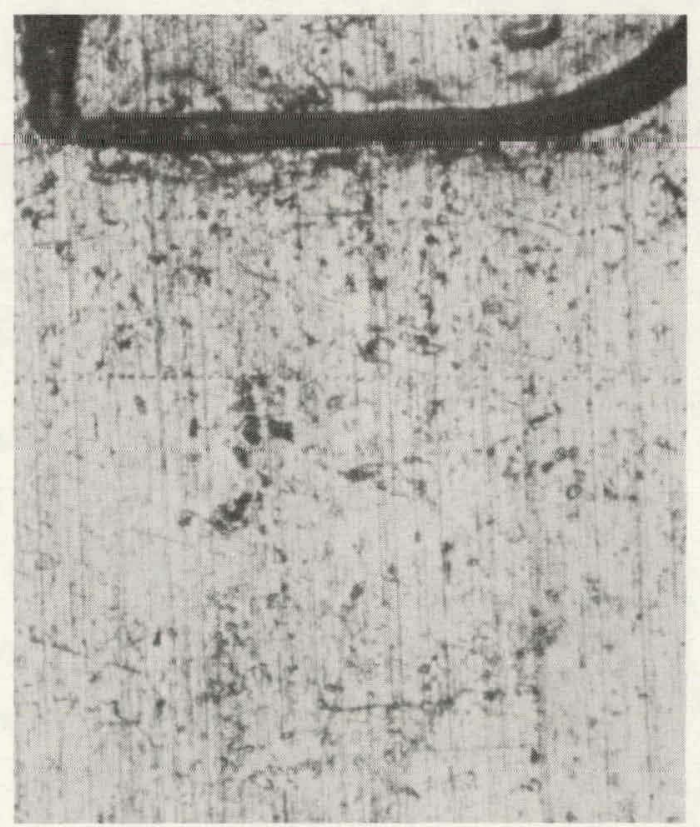

(d) Side B, after.

Figure 21. STEEL; DEARBORN-537 TREATMENT (4 DAYS AT $84^{\circ} \mathrm{F}, 28$ DAYS MOIST-AIR EXPOSURE). (50X) 


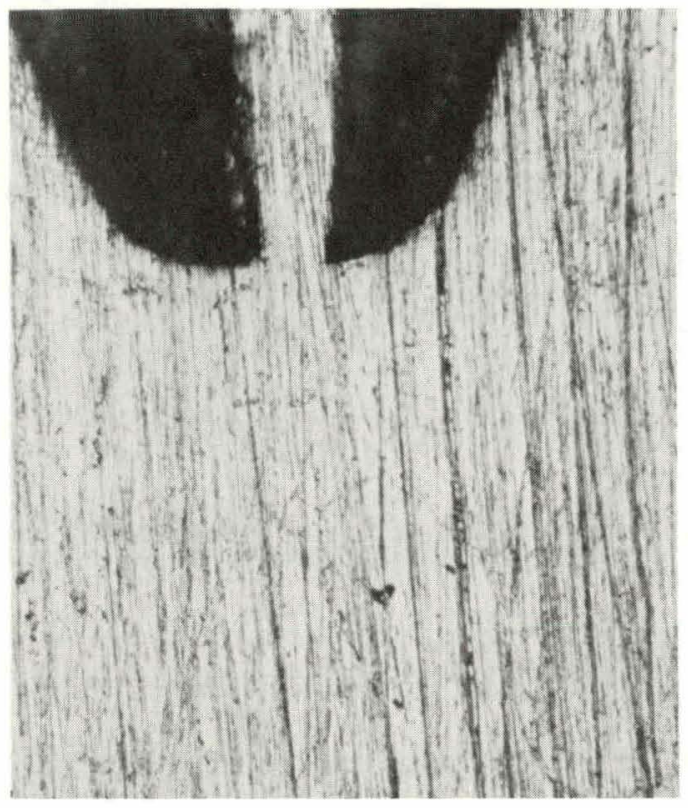

(a) Side A, before.

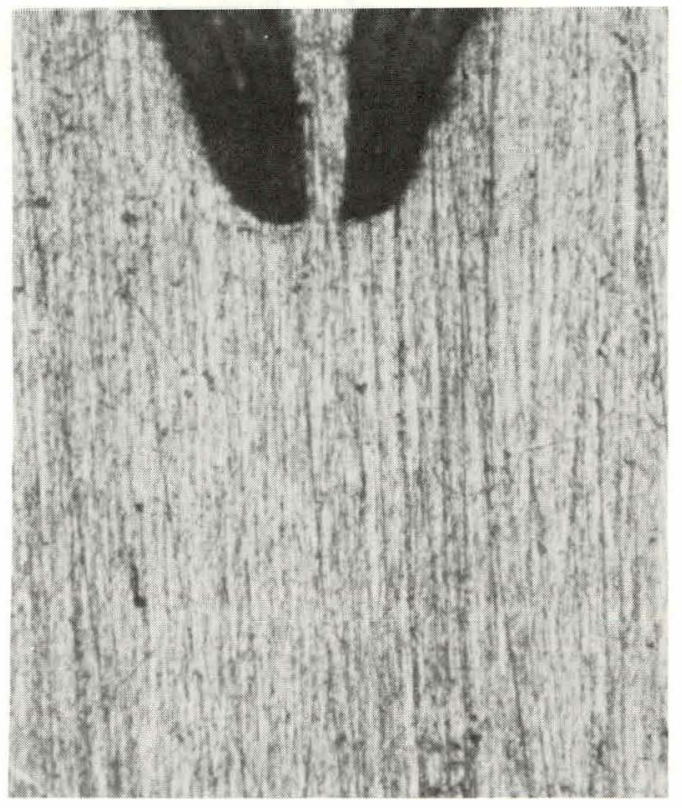

(b) Side A, after.

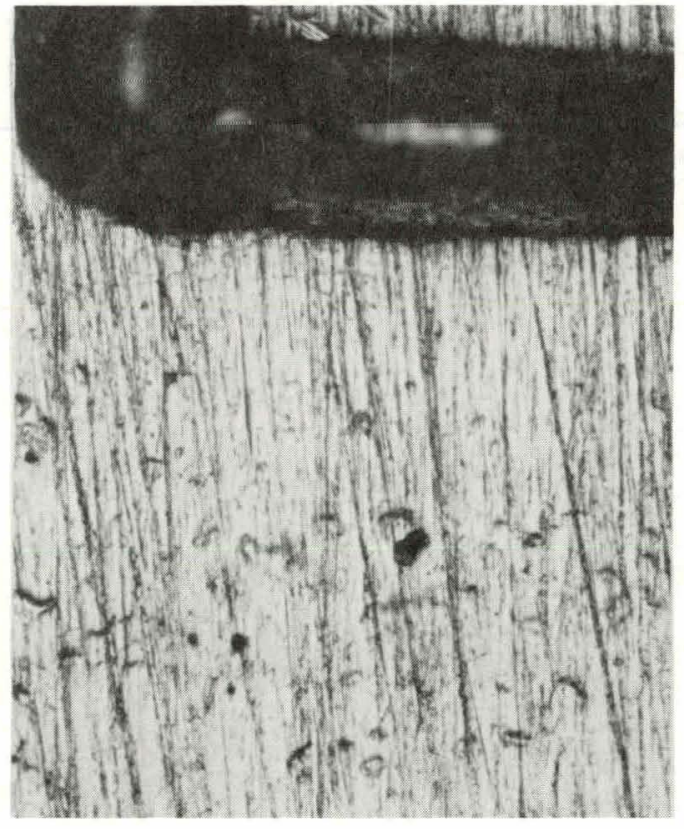

(c) Side B, before.

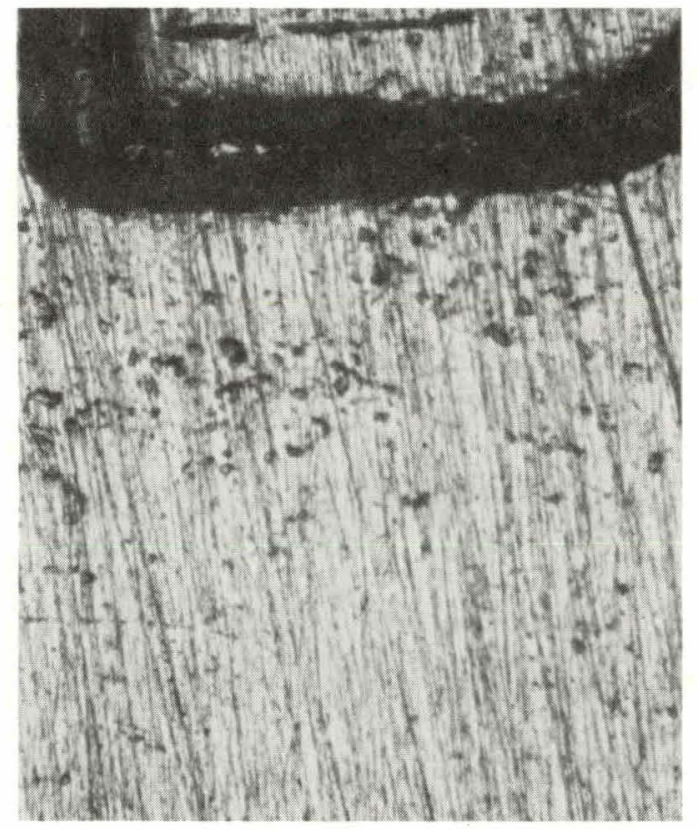

(d) Side B, after.

Figure 22. STAINLESS STEEL; DEARBORN-537 TREATMENT (4 DAYS AT 84 ${ }^{\circ} \mathrm{F}, 28$ DAYS MOIST-AIR EXPOSURE). (50X) 
test. Zimmite ZC-404 is a synergistic blend of corrosion and deposit inhibitors for use in recirculating cooling-water systems. It does not contain chromates, phosphates, or zinc salts and, therefore, does not contribute to pollution according to the Zimmite Corporation's product data sheet.

Analytical data obtained on the treated water using Zimmite ZC-404 are summarized in Table 7. Weight-change data obtained on the metal coupons exposed for $21 \mathrm{~d}$ are summarized in Table 8. Photomicrographs of test coupons exposed to the Zimmite treatment were not taken in order to reduce costs of the experimental test program.
Table 7

ANALYSIS OF ZIMMITE ZC-404-TREATED WATER USED FOR CORROSION TEST

\begin{tabular}{lc}
\hline $\mathrm{pH}$ & 10.5 \\
Boron (ppm as $\mathrm{B}$ ) & 6.6 \\
Nitrite (ppm as $\mathrm{NO}_{2}$ ) & 101 \\
Silicon (ppm as $\mathrm{SiO}_{2}$ ) & 27.4 \\
\hline
\end{tabular}

Table 8

CORROSION-TEST-COUPON WEIGHT CHANGES ACCOMPANYING ZIMMITE ZC-404 COOLING-WATER TREATMENT

\begin{tabular}{llrrr}
\hline & \multicolumn{1}{c}{ Metal Type } & \multicolumn{3}{c}{ Weight (g) } \\
\cline { 3 - 5 } Specimen & \multicolumn{1}{c}{ Initial } & \multicolumn{1}{c}{ Final } & Change \\
\hline M-6 & Aluminum Alloy 3003-H1 & 5.0201 & 4.9945 & -0.0256 \\
M-7 & Aluminum Alloy 3003-H1 & 5.0205 & 4.9957 & -0.0248 \\
A-6 & Aluminum Alloy 6061-T6 & 6.1711 & 6.1524 & -0.0187 \\
A-7 & Aluminum Alloy 6061-T6 & 6.2397 & 6.2080 & -0.0317 \\
$51-Y$ & Steel & 13.6128 & 13.6129 & +0.0003 \\
$64-Y$ & Steel & 13.6614 & 13.6614 & 0.0000 \\
AA-7 & Copper & 21.3707 & 21.3710 & +0.0003 \\
AA-8 & Copper & 21.5192 & 21.5196 & +0.0004 \\
BM-6 & Muntz Metal (60\% copper, 40\% zinc) & 19.4038 & 19.4040 & +0.0002 \\
BM-7 & Muntz Metal (60\% copper, 40\% zinc) & 19.8243 & 19.8243 & 0.0000 \\
SS-6 & Stainless Steel 304L & 17.0769 & 17.0771 & +0.0002 \\
SS-7 & Stainless Steel 304L & 17.2212 & 17.2216 & +0.0004 \\
\hline
\end{tabular}

\section{DISCUSSION}

The Dearborn-537 corrosion-inhibitor formulation used in this study was a purple-colored aqueous concentrate. It was used in the cooling-water test system by adding $3.8 \mathrm{~L}$ (1 gal) of concentrate per $378 \mathrm{~L}$ (100 gal) of system water in accordance with Dearborn Product Bulletin 6258.

The DOE-patented inhibitor formulation was made up by additions of weighed amounts of laboratory reagent-grade chemicals, i.e., sodium metasilicate $\left(\mathrm{Na}_{2} \mathrm{SiO}_{3}\right)$, sodium nitrite $\left(\mathrm{NaNO}_{2}\right)$, sodium tetraborate $\left(\mathrm{Na}_{2} \mathrm{~B}_{4} \mathrm{O}_{7}\right)$, and impalpable boric acid. A dosage of 5-ppm tolyltriazole, a specific inhibitor for copper, was also used. This treatment was accompanied by $30 \mathrm{ppm}$ of an aqueous commercial microbiocide, Chemtrol-19, (e) which consists chemically of a $30 \%$ solution of poly [oxyethylene(dimethyliminio)ethylene(dimethyliminiolethylenedichloride]. The formula for the rompound is: 


$$
\left[\mathrm{O}-\mathrm{CH}_{2}-\mathrm{CH}_{2}-\mathrm{N}-{ }^{+}\left(\mathrm{CH}_{3}\right)_{2} \mathrm{Cl}-\mathrm{CH}_{2} \mathrm{CH}_{2} \mathrm{~N}^{+}\left(\mathrm{CH}_{3}\right)_{2} \mathrm{Cl} \mathrm{CH}_{2} \mathrm{CH}_{2}\right]_{\mathrm{n}} \text {. }
$$

The Zimmite ZC-404 inhibitor formulation used in these tests (an amber-colored aqueous concentrate) was used in the system water by adding $1 \mathrm{~g}$ of concentrate per gal $(3.8 \mathrm{~L})$ of waste in accordance with Zimmite instructions for use. As shown in Table 7, this treatment provided an unusually high $\mathrm{pH}(10.5)$ and considerably lower concentrations of boron and silicon than did the Dearborn-537 or the DOE-patented inhibitor formulations. The corrosion-coupon weight-loss data, as shown in Table 8, also reflect these lower concentrations of inhibitor ingredients and high $\mathrm{pH}$ attack of aluminum alloys in that the aluminum. alloy 3003-H1 and aluminum alloy 6061-T6 coupons showed an average weight loss of approximately $25 \mathrm{mg}$ as compared to weight losses of essentially zero or even slight weight gains for the other two treatments as shown in Tables 1, 3, and 5. For an aluminum-alloy corrosion test coupon to show a slight weight gain is normal inasmuch as corrosion protection is conferred upon aluminum by the establishment of a protective film or coating of aluminum oxide hydrate.

From the weight-loss data shown in Table 8 for the aluminum-alloy test coupons exposed to the Zimmite 2C-404 inhibitor lusing an average weight loss of $25.2 \mathrm{mg}$, a specimen area of $0.292 \mathrm{dm}^{2}$, an exposure period of $21 \mathrm{~d}$, and a density of $2.72 \mathrm{~g} / \mathrm{mL}$ for aluminum), the average corrosion penetration rate for aluminum was calculated to be 2.2 mils per year.

As an overall conclusion from an examination of the weight-loss corrosion data and photomicrographs of fiducial marks on metal test coupons before and after exposure, the $Y$-12, DOE-patented blend of corrosion inhibitors provided the best, uverall, corroslon protection. As shown in Table 6, this treatment also utilizes a higher concentration of dissolved nitrite, boron, and silicate inhibitors to achieve this degree of protection.

It should be recognized that (1) the 21-d or 28-d corrosion-test evaluation periods used in this study are considered to be the absolute minimum from the standpoint of obtaining meaningful corrosion data and (2) that longer evaluation periods should be used in subsequent corrosion tests. The urgency of the ORGDP program, however, precluded any longer term corrosion evaluation. In future water-treatment evaluation studies, the effect of heat-transfer conditions on scale formation and the compatibility and effectiveness of microbiocides should also be investigated. 


\section{ACKNOWLEDGMENTS}

Grateful acknowledgments are extended to L. F. Deroos and E. W. Wester of the Product. Certification Metallurgy Laboratory for photomicrographs of metal test coupons. 


\section{REFERENCES}

1. F. D. Mikelson, Operating Contractors Project Office, Portsmouth Gas Centrifuge Enrichment Plant, Oak Ridge, Tenn., Private Communication (August 7, 1978).

2. "Corrosivity Testing of Industrial Cooling Water (Coupon Test Method)," Cooling Water Treatment Manual, Technical Practices Committees Publication 1, National Association of Corrosion Engineers, Houston, Tex. 


\section{Distribution}

Department of Energy - Oak Ridge

Hickman, H. D.

Poteat, R. M.

\section{Goodyear Atomic Corporation}

Caivdry, S. 8.

Robinette, R. J.

Storage, M. R.

Wiehle, W. E.

Lawrence Livermore National Laboratory

Arnold, W. F.

Los Alamos National Scientific Laboratory

Hoyt, H. C.

\section{Oak Ridge Gaseous Diffusion Plant}

Armstrong, R. C.

Carlson, E. E.

Evans, E. C.

Hickey, M. H., Jr.

McWhorter, J. R.

Napolitan, D.S.

ORGDP Library

Orrison, R. G.

Reed, W. D.

Robinson, D. T:

Stief, S. S.

White, H. C.

Wilcox, W. J., Jr.

Oak Ridge National Laboratory

Cox, J. A.

Hopkins, C. C.

\section{Oak Ridge Y-12 Plant}

DeMoribrun, J. R. (3)

Dodson, W. H./Googin, J. M.

Evans, G.W.

Fraser, R. J.

Keith, A.

Kite, H. T.
Mills, J. M., Jr.

Parsons, J. A. (2)

Schmitt, C. R. (15)

Stickle, E. T.

$Y-12$ Central Files (master copy)

$Y-12$ Central Files (route copy)

$Y-12$ Central Files $(Y-12 R C)$

$Y-12$ Central Files (5)

Paducah Gaseous Diffusion Plant

Bewley, H. D.

Tuholsky, A. M.

Sandia National Laboratories - Livermore

Spencer, W. J.

Union Carbide Corporation - New York

Tinsley, S. W.

In addition, this report is distributed in accordance with the Category UC-25, Materials, as given in the Standard Distribution for Unclassiried Scientific and Technical Reports, DOE/TIC-4500. 